平成 3 年レーザー学会学術講演会第11回年次大会

30p V 1 自由電子レーザーにおけるマルチ周波数シミコレーションコードの開発

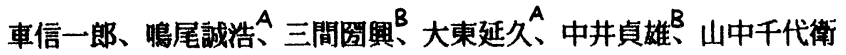

（（財）レーザー総研、A 関西大、B 阪大レーザー研）

自由電子レーザーにおいて、従来のシミュレーションコードでは無限長の奄子ビームと單一周波数の電磁波 の相互作用しか記述できなかったか、実際の電子ビームは有限のバルス幅を持っており、励起される電磁波 あ有限なバルス幅、スペクトル幅を持つ。本シミュレーションコードでは放射光を多重周波数として取り扱 うことにより電子ビーム及び放射光のバルス効果を考慮した相互作用を記述できる。

〔モデル方程式〕電子ビームの運動方程式は各柆子のエネルギーと位相に対し次式で与えられる。 $r i^{\prime}=-(K / 2 \gamma i \beta z i) \sum_{n}(A s n \exp (i \psi n i)+c . c),. \quad \psi n i{ }^{\prime}=1-k s n(1-\beta z i) / \beta z i$, また電磁波の波動方程式は 、Asn' $=\left(\omega p^{2} k \quad \beta z 0 / 2\right)<\exp (-i \psi n i) / \beta z i r i>, こ こ て ゙ 、 \beta z i=\left(1-\left(1+k^{2} / 2\right) / \gamma i^{2}\right)^{1 / 2}, k=93.4 B w(T) \lambda w(m)$ はk バラメーター、 $\omega \mathrm{p}, \mathrm{Asn}$ は、 kWC で規格化したビームブラズマ周波数及び電磁波の振幅、ブライムはkW Z での微分を表す。また、く...> は全柆子に対する平均を表す。光の波数仁関しては、中心波数ks0 のまわ りに、 $k s n=k s 0+\Delta k n=k s 0(1+n / 100) ，(n=1,2, \ldots)$ とした。これらの式を連立しルンダクッタ法で解くこ とにより電子ビームバルス及び電磁波バルスの非線形空間発展を記述できる。

〔数值例】バラメーターとしては大阪大学レーザー核融合研究センターで計画中のR F ライナックを電子

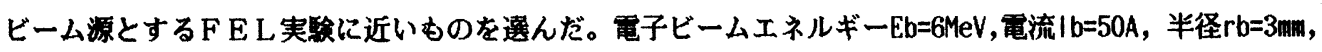
パルス幅 $r \mathrm{~b}=50 \mathrm{psec}$, エネルギー拡がり $\Delta r / r=1 \%$, ウィグラー周期 $\lambda \mathrm{w}=6 \mathrm{~cm}$, 磁場強度B $\mathrm{B}=3.2 \mathrm{kG}$, ビッチ数

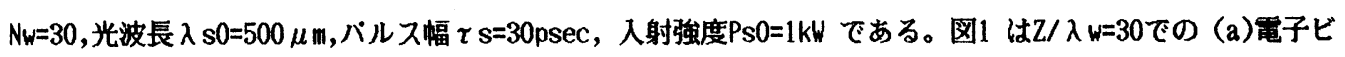
一ムバルスのエネルギー分布、(b) 光バルス及び(c) スベクトルを表す。電子ビームバルスが光バルスに比

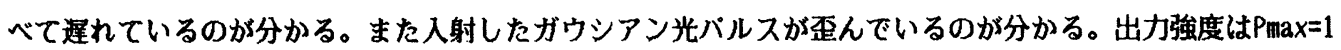
.56MWで利得は $31.8 \mathrm{~dB}$ である。

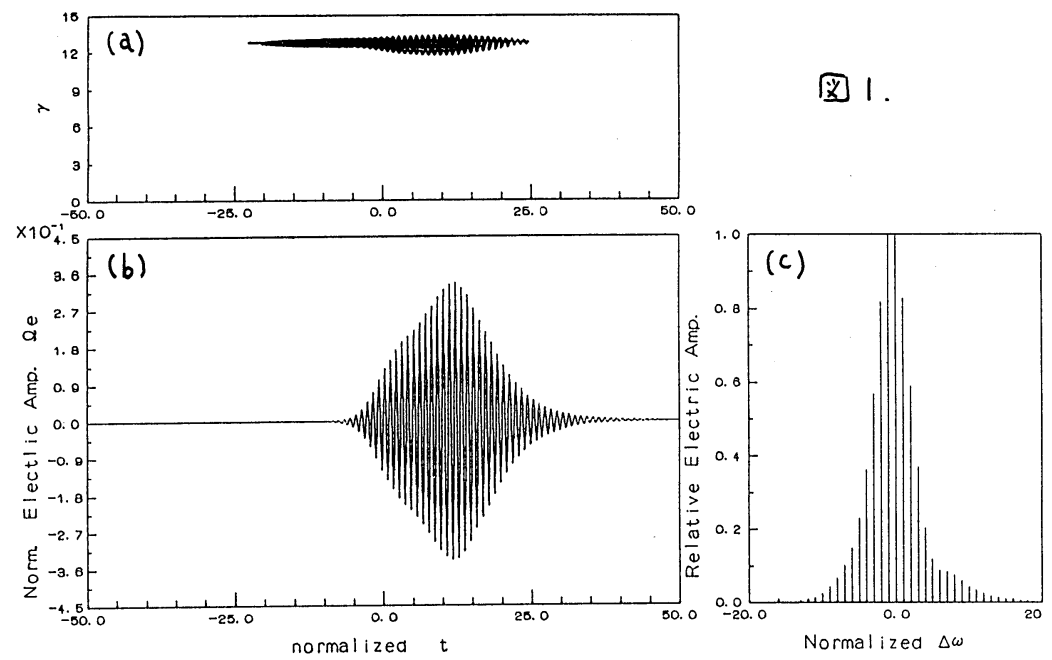

国1. 
平成 3 年レーザー学会学術講演会第11回年次大会

30p V 2

収束型ウィグラーの彆作とシミュレーション

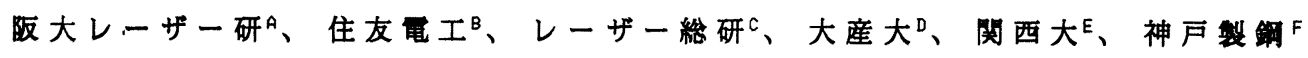

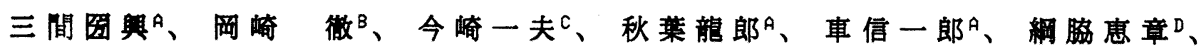
大東延久E、鳴尾誠浩E、小林明F、川田豊F、中井貞雄 ${ }^{A}$

自由電子レーザ研究会と阪大レーザー研では、収束機能を持った台形磁極ハイブ リッドウィグラーを開発している。これは、ハィブリッドウィグラーの鉄磁を 台形とすることにより、轵横両方向に収東力をもたせた物である。主な寸法は、 全長 $1 \mathrm{~m} k$ 対してウィグラピッチ $2 \mathrm{~cm}$ m 50 ピッチであり、磁石幅 $8 \mathrm{~cm}$ 、磁石 厚み $1.5 \mathrm{~cm}$ 、ギャップ间隔 $1 \mathrm{c} \mathrm{m}$ である。台形磁には電磁軟鉄を用いてお りその傾き角度は 1 度、また磁石にはネオジウム系永久磁石を用いた。更にこの ウィグラーの後半 $40 \mathrm{~cm}$ には電磁石をウィグラの背面より取り付けており、これ により磁東をビーム軸の背面にバイパスし、かっこのバイパス量をコントロールす ることができる。これにより電子ビーム軸上において磁場のテーパー化及び微調 整ができる(図 1 )。

ウィグラーの磁場測定はホール素子を用いて行っており、ビーム軸上及び水平 方向にずれた軸上の磁場を測定した。この結果を困 2 に示す。両端の3ピーク を除き、磁場のピーク值の諆差は士1.3\%以下となっている。この值を用い、 $\mathrm{Z}$ 軸に成して二階㩧分すると水平方向の入射位固と出射位圆は等しくなり、良好な 磁場特性を持っていると考えられる。

なお実験においては入射器として阪大レーザー研の $4 \mathrm{MeV}$ - $10 \mathrm{k} \mathrm{A}$ 誘導 イナックを使用する。

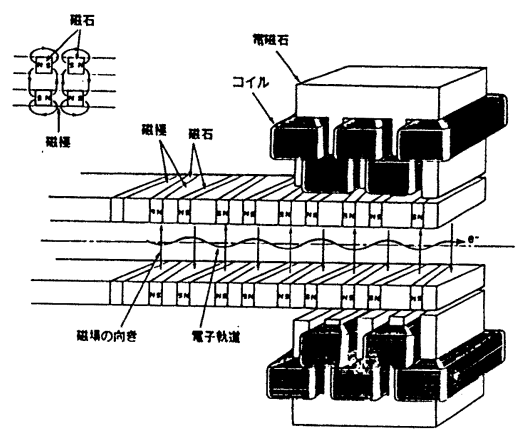

四1開発したウィグラーの概念困

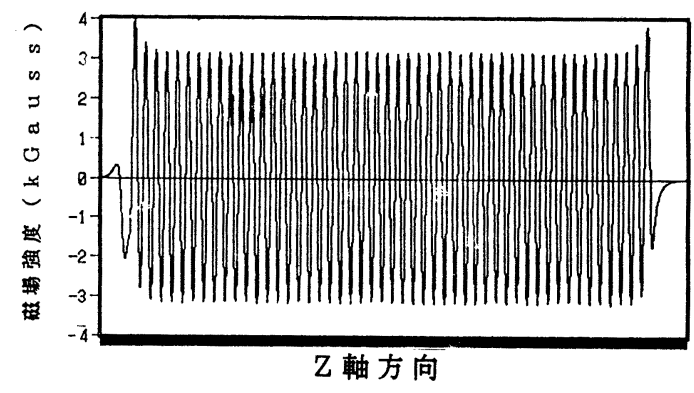

因 2 ウィグラー磁場分布 
平成 3 年レーザー学会学術講演会第11回年次大会

$30 \mathrm{p} \mathrm{V} 3$

収束型ウィグラーの実験的研究

秋葉龍郎、大谷英成、吉田昌只、青木宗和 ${ }^{B} 、$ 森井健 ${ }^{C} 、$ 宮本修治、

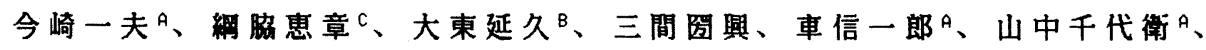

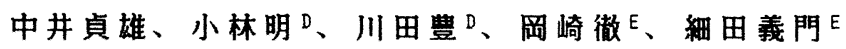

（阪大レーザー研、A：レーザー総研、B：関大工

$\mathrm{C}$ ：大阪産大、 $\mathrm{D} ：$ 神戸製鉠、 $\mathrm{E} ：$ 住友電工）

ウィグラーには、一般に平面ウィグラーとヘリカルウィグラーがある。ヘリカルウ くグラーでは、数 $\mathrm{kG}$ オーダーの磁場を発生させには超伝導コイルを用いる等の手法 を採らなければ困難である。一方平面ウィグラーでは強磁場の発生が比較的容易であ る。しかし、通常の平面ウィグラーでは、磁場の方向（ $\mathrm{y}$ 方向）では収束作用が強く、 電子のウィグル運動面内（ $x-z$ 面内）では収束力は皆無である。そこで、四極子磁 石を用いるなどの電子ビームを伝搬させるための方法が必要である。今回は電子の収 束伝搬を目的としてハイブリッドウィグラーを開発した。ハイブリッドウィグラーと は、图1に示す样に平行四辺形の永久磁石と台形の強磁性体の組合せにより、ウィグ ラー自身に $\mathrm{x}-\mathrm{y}$ 両方向の収束作用をもたせるのである。すなわち、ウィグラーの中 心軸からより多く離れた地点を飛ぶ電子は、強磁性体が台形になっているため磁場の 影慗をうけるパスが長くなり、収束される。

開発したウィグラーはピッチ $20 \mathrm{~mm}$ で、ピッチ数 50 、磁場強度は約 $3 \mathrm{k} \mathrm{G}$ であ る。このウィグラーに誘導加速器で発生した電子ビーム（エネルギー $2 \mathrm{MeV}$ 、ハハル ス幅 $100 \mathrm{n} \mathrm{s}$ ) を打ち込みウィグラー中の伝般の実験を行う。初期の傾き角を変え て、1個の電子をこのウィグラー中に打ち込んだ場合の軌道の計算結果を图 2 に示す。 $\mathrm{x}$ 方向のベータートロン波長は、約 $45 \mathrm{~cm}$ である。 $\mathrm{y}$ 方向もほほ同様の值である。 今回の実験のウィグラーノ導波管では、アクセプタンスは $0.17 \mathrm{rad} \cdot \mathrm{cm}$ である。学 波管の大きさは $8 \mathrm{~mm} \times 16 \mathrm{~mm}$ である自由電子レーザーの実驗としては、炭酸ガ

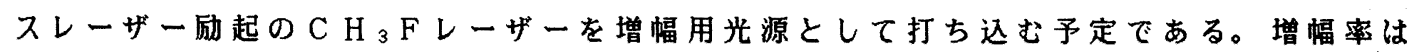

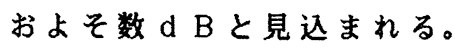

詳細は講演時に譲る。

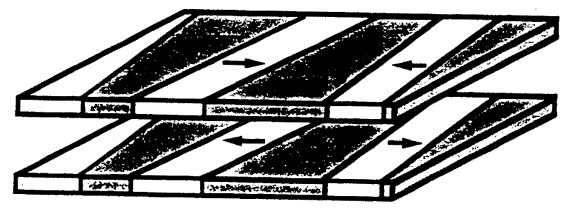

強磁性体 永久磁石

図1ハイブリッドウィグラー

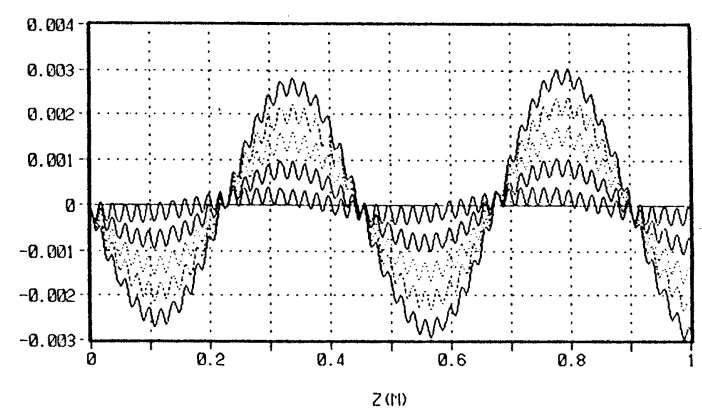

図 2 ハイブリッドウィグラー中での 電子軌道

（初期条件： $x_{\theta}=0 \mathrm{~mm}^{\circ} x_{\theta}{ }^{\prime}= \pm 16 \mathrm{mrad}$ ) 
平成 3 年レーザー学会学術講演会第11回年次大会

$30 \mathrm{p} \mathrm{V} 4$

西子ビ一ム收束

網照恵章, 大東 延久 ${ }^{\mathrm{A}}$, 岡崎 徽 ${ }^{\mathrm{B}}$, 三間 图興 ${ }^{\circ}$, 車 信一郎 ${ }^{\mathrm{D}}$, 秋葉 龍郎 ${ }^{\mathrm{C}}$, 今崎一夫员, 細田義門 ${ }^{\mathrm{B}}$, 佐藤信二 ${ }^{\mathrm{E}}$, 中井貞雄 ${ }^{\mathrm{C}}$

大産大工, A 関大工, B 住友電工, C 阪大レーザー研, D レーザー総研, E三菱電機

1.はじめに FEL用ウィグラーとして棒状永久磁石 4 組を 1 周期とする、いわ的 Halbach型ウィグラーがよく知られている。このような平面ウィグラーの場合、ウィグラー面内に拀 いては電子ビームを収束させる作用はない。従って一般に四重極多补を組み合わせる などして、ビー昿がりを小さくするようにエ夫されている。本研究では、図 1 に示す ようにウィグラーの磁苏形状を湾曲させたとき、および台形状にしたときのウィグラー自身に よる電子ビーム収束作用について検討した。

2. 計算方法 ウィダラー中の磁場強度分布解析は、1ケの永久磁石に対する電流王 デルに基いたBiot-Savartの式をむとに得られた磁場を全磁石に わたって積算して求めた。また電子軌道解析は、電子は互いに 作用することなく伝般するとしてLorentzの関係式を用いて行

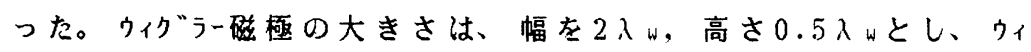
グラー 中心の磁場は K 值が 1 となるような磁極間隔を選んだ。 (2)

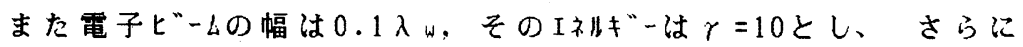
得られた結果が一般化できるようビームはウィグラー中心て収束して (3) いるとした。

3. 結果図1（1）のように磁極全幅にわたって湾曲させて 屯電子ヒ”－Lの収束性はそれ程改善されなかった。図1(2)のよう(4) に中心部のみ半円近く湾曲させると、例えば図2のように大き

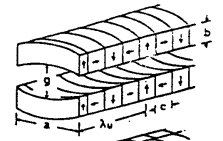
く収束性が增大するのが見られた。しかしウィグラー面に 垂直な方向 $(Y)$ では逆に広がる。図 3 はX.Y方向のビーム 幅およびßトロ振動の波長を湾曲の曲率の関数として

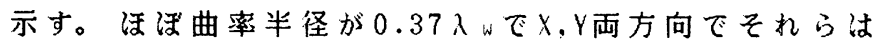
等しくなるのが見られる。同样に図1(3)(4)の台形状 磁極をもつウィグラーの場合につい ての結果を図4に示す。 $\theta$ の增 加と共に汸向に汉収束性が增し、 方向には広がり、 $\theta \sim 1.2^{\circ}$ て ビーム幅および 纺向で等しくなる。このように ビーム収束性を改善したウィグラーを 用いたFELの利得についてさらに 計算機シミュレーションで検討中である。

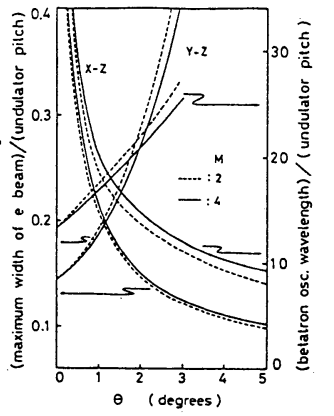

図 4
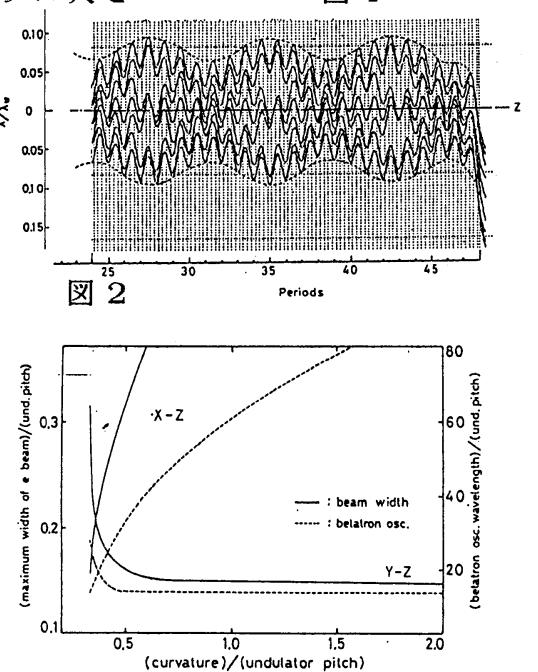

図 3 


\section{平成 3 年レーザー学会学術講演会第11回年次大会}

$30 \mathrm{p} \mathrm{V} 5$

F E L 用高輝度電子ビーム源の開発

PHOTOCATHODE実験

。浅川 誠、安芸寿彦、秋葉龍郎、大谷英成、青木宗和 ${ }^{\natural} 、$ 森井健 ${ }^{\mathrm{B}} 、$

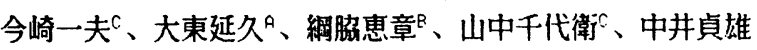

（阪大レーザー研、A：関大工、B：大産大、C：レーザー総研）

F E L 用高煇度電子ビーム源としてフォトカソードの開発を行っている。RFガンとフォト カソードを組み合わせることによりバルス幅 $10 \mathrm{p} \mathrm{s}$ 、規格化輝度 $10^{11} \mathrm{~A} / \mathrm{m}^{2} / \mathrm{rad}^{2}$ 、 ビーク電流数十Aの電子ビームを発生できる。この様に初めからバンチングされた電子ビーム は、RFライナックでの加速に於て大きなエミッタンスの劣化を受けない。

フォトカソードとして調查した材料を图 1 に示す。またフォトカソードドライブ用には $\mathrm{N} \mathrm{d}$ : Y A Gレーザー（パルス幅 $10 \mathrm{~ns}$ ）を用いた。従来、フォトカソードとして用いられてき た半筫体化合物 ( $\mathrm{C} \mathrm{s}_{3} \mathrm{~S} \mathrm{~b}$ 等) は、フォトエミッションの臨界波長が $550 \mathrm{~nm}$ 程度であり 高量子効率であるが、レーザーに対する耐久性が低く高電流密度の電子ビーム源としては不向 きである。従って、金属（仕事関数～ $5 \mathrm{e} \mathrm{V}$ ）を用い多光子吸収によるフォトエミッションを 利用したフォトカソードの開発を行っている。また、高量子効蜜のカソードとしてL a B 6 （ 仕事関数〜3. $5 \mathrm{e} \mathrm{V}$ ) などの金属化合物の調査む行っている。実験では各材料についてレ 一ザーの波長及び入射角度を变え、各々の場合について光電子電流のレーザーバワー依存性を 調べている。图 $2 に L$ a $B_{6}$ 単結晶（（１００）、波長 $3 \omega$ 、入射角度 $83^{\circ}$ の結果を示す。

また量子效率およびエミッションの安定性の改善のためにカソードを加熱して（～1400

。C）レーザーパワー依存性を調査している。高温度領域ではレーザーの照射によるカソード

温度上昇のために熱電子電流の増加が起きトータルの電流量を増やしていることを確認した。

Dependence of the Photocurrent

\begin{tabular}{|c|c|c|}
\hline \multicolumn{2}{|c|}{ Material } & Work Function (eV) \\
\hline $\mathbf{W}$ & Polycrystal & 4.5 \\
\hline Al & Polycrystal & 4.0 \\
\hline $\mathrm{LaB}_{6}$ & Polycrystal & $\sim 3.5$ \\
\hline $\mathrm{LaB}_{6}$ & Single crystal & 2.6 \\
\hline TiC & Polycrystal & / \\
\hline
\end{tabular}

\section{Nd:YAG Laser}

Pulse Length : 10ns (FWHM)

Energy : $2 \omega \quad 450 \mathrm{~mJ}$

$3 \omega \quad 150 \mathrm{~mJ}$

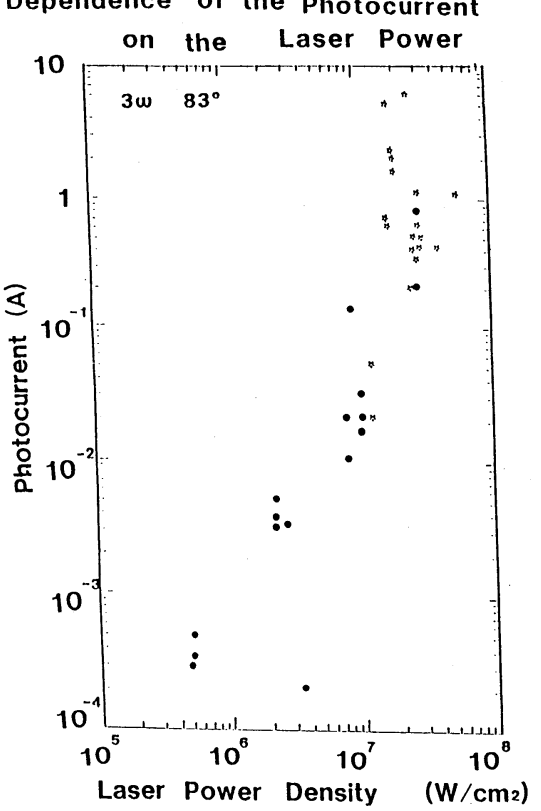


平成 3 年レーザー学会学術講演会第11回年次大会

30p V 6 コールド相対論的電子ビームによる自由電子レーザーの研究 $-\mathrm{V}$

(電磁波による電子ビームの変調)

河村良行、豊田浩一、李陃鐵・（理化学研究所、暲国通研“)

1.はじめに

自由電子レーザー（· F L ）の発振に は質の良い（エネルギーの揃った）相対 論的エネルギーを持つ電子ビームが不可 欠である。発掁が成長するまでの間、電 子ビームの加速エネルギーの变化が少な いことも必要な条件になる。我々は比較 的大きな電流が得られ、かつ上記の条件 を满足するコールド相対論的電子ビーム （ＣＲＢ）を用いFE L 発振実験を行 なっている。

\section{2. 実験 結果}

図 1 に F E L 発振実験装置を示す。電 子ビーム、ウィグラ一、導波管共振器は 前回までに報告したるのと同様である。 今回は導波管中心部の電流波形をモ二夕 一する為に、石英ファイバーを中心軸上 に設置し、電子ビームによって誘起され るチェレンコフ光の強度を計測した。フ フイバー中での分散が信号に影整を与え ることを防ぐ為に、チェレンコフ光の内 の $410 \pm 5 \mathrm{~nm}$ のスペクトル成分のみ を光電子增倍管によって测定した。

図2, に発振波形、導波管中心部を通っ た電流波形、及び全電流のフーリエ解析 の結果を示す。導波管中心部を通った電 流にのみ発振波形と同一のフーリエスペ クトル成分が観测され、発振電磁波によ り変調を受けていることが分かった。詳 細は講演に譲る。

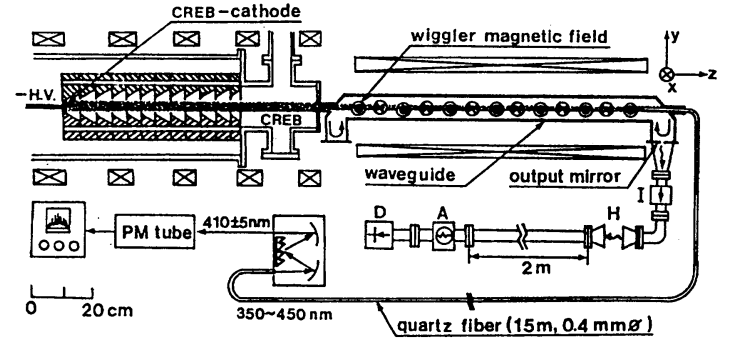

図 1 . 実験装置概略

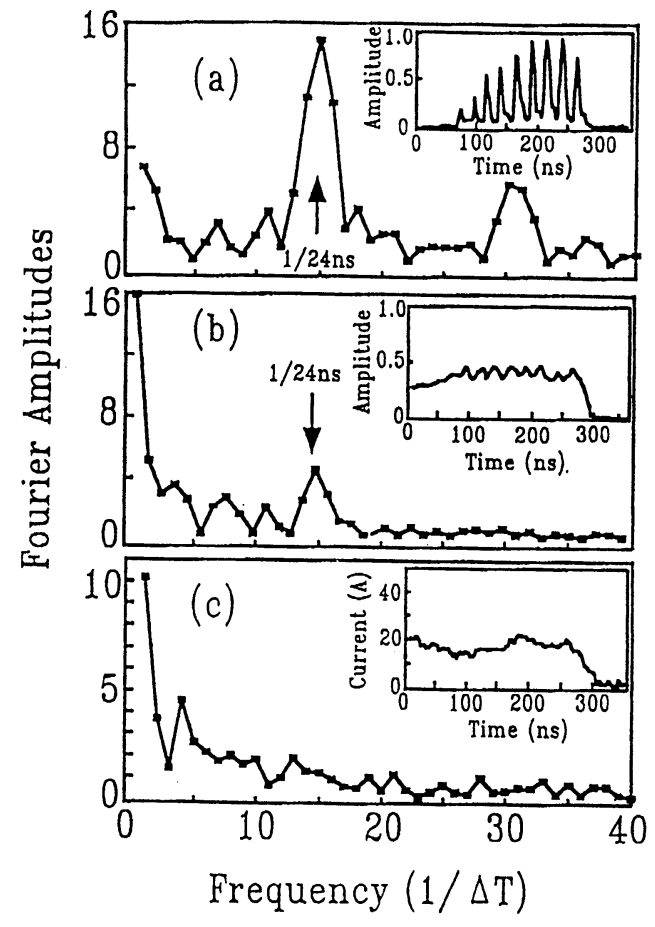

図2.（a）発振波形のフーリエ解析、 （b）導波管中心部を通った電流のフー リエ解析、 ( c ) 全電流のフーリエ解析 


\section{平成 3 年レーザー学会学術講演会第 11 回年次大会}

30 p V 7

光炀起遠赤外リングレーザーの出力方向特性

松島恭治 - 東田憲佳 ${ }^{\mathrm{A}}$. 曾我部伸 ${ }^{\mathrm{A}} \cdot$ 村井昭 $\mathrm{A}$. 有安富雄 （関西大工・A大阪市大工）

リングレーザーは、その開発の当初より互いに逆方向に進行する二つのレーザー光の干 涉効果を用いた高感度の回転運動検出器として研究が進められて来た。また近年では、共 振器内に捕入した光学素子によって単一方向のみの進行波を発振させ、媒質に生じる空間 的なホールバーニングを除去することを目的とした色素リングレーザーも開発されている。

これらのリングレーザーでは、逆方向に進行する二つのレーザー光を積極的に利用する か、付加的な手段を用いて除去するかの違いはあるが、どちらも本質的には互いに逆方向 に進行する二つのレーザー光が生じることには変わりはない。しかしながら、光励起遠赤 外リングレーザーの場合には特別な機構を必要とせずに自発的に単一方向の進行波で発振 が起きることが知られている[1]。また、その出力の方向が共振器周波数に依存して変化す ることが観測されており、これらの原因が共振器内のレーザー光の進行方向に対する利得 曲線の不一致であるとして説明されている。しかしながら、利得曲線の不一致はわすがで あり、それだけではこの現象を説明できない。そこで、我々はこの自発的な単一方向発振 の現象を実駼的に確認し、また 2 モードレーザー理論を用いてこの現象の解析を行った。

図 1 に実験装置を示す。実験には $\mathrm{CO}_{2} レ$ レ゙ーの9P(36) 線で励起される $\mathrm{CH}_{3} \mathrm{OH}$ の $119 \mu$ 線 を用いた。リング共振器は $M_{1} \sim M_{4}$ の 4 枚のミラーで搆成し、 $M_{1}$ の開口上に焦点を結ぶ凹面 ミラーを用いて励起光を導入し、前方出力として $\mathbf{M}_{2}$ より、また後方出力として产より遠赤 外出力を取り出した。M 2 を保持しているステージを微動して共振器長を掃引した時のそれ ぞれの方向の遠赤外出力の変化を図2(b)に示した。また比較のためファブリーペロー型共 振器の場合の同調曲線を図2(a)に示した。(a)では遠赤外遷移の中心周波数を中心としたほ ぼ対称な出力曲線であるのに対し、（b）では図中の波線で示した対称の中心より周波数が低 い側では前方出力がまた高い僋では後方出力が強く発振していることがわかる。

講演ではこの実験結果と、3 準位模型に 2 モードレーザー理論を適用した解析の結果を 報告する。

[1] J.Heppner and C.0.Weiss: Appl. Phys. Lett. $\underline{33}$ (1978)590.

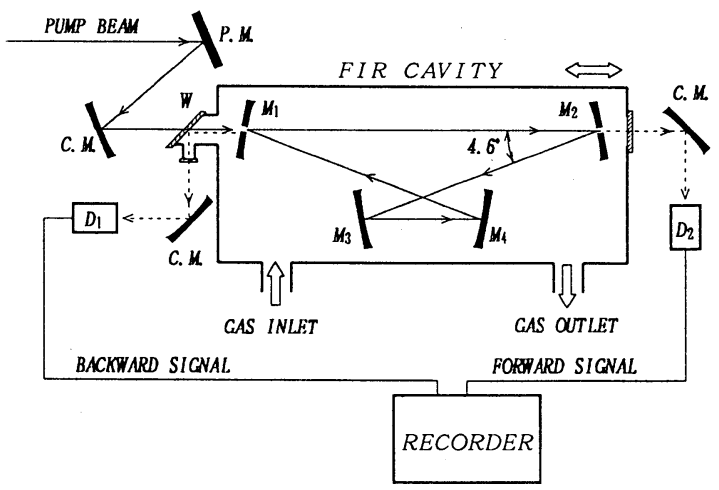

図 1 光励起遠赤外リングレーザー
590

図 2

共振器同調曲線

(b)
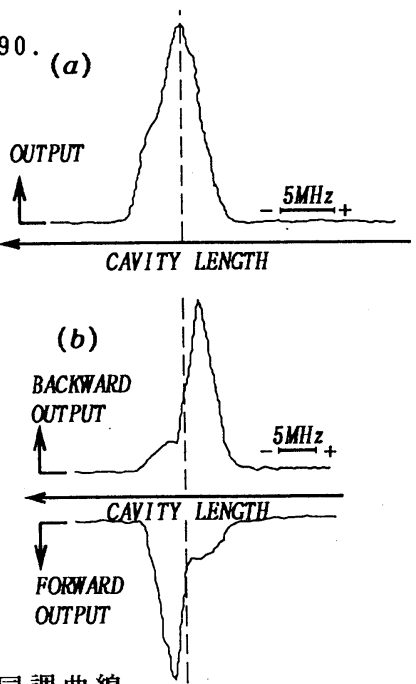
平成 3 年レーザー学会学術講演会第11回年次大会

31a IV 1

矩形ハイビークパルスSD励起COェレーザ

一PURE適用による高出力化一

暮本昌榯、竹中裕司、森安雅治 ${ }^{\wedge}$

(三菱要機株式会社 中央研究所、生産技術研究所 ${ }^{A}$ )

\section{1、まえがき}

入熱コントロールの可能なパルス出カによるレーザ加エが注目されている。䇤者 らは、加工材料の熟伝導時間に相当する $100 \mu \mathrm{sec}$ 程度のパルス幅を持つ高ビーク（5 $\mathrm{kW}) \mathrm{CO}_{2} レ$ レ゙の開発により、セラミクスをはじめとする硬臲性材料の精密加工を実 現したい”。今後、用途拡大のため、更なる高ビーク化が求められている。

本論では、全く新しい位相整合共振器(PURE)による、大口径・高品質ビームの取り 出し技術と、この技術によるレーザ出カの高ビーク化について述べる。

\section{2、実験}

電界緩和型セラミクス電極を用いた実験装置は前報告いと同様である。共振器構 成を図1に示す。不安定型共振器の中央部からもレーザビームを出カし、さらに、中 央部と周辺部を通過するレーザビームの位相を揃えることにより高集束ビームの取 り出しを実現する共振器である(2)。位相整合ミラーの曲率半径 $R_{1}$ おび中央部透 過率 T。は、それぞれ R

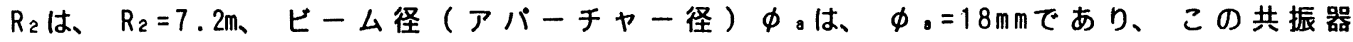
の拡大率 Mおよび等価フレネル数 Neaは、それぞれ M=1.5およびNea=0.5である。 ビームモードの测定は、ナイフエッジ法を用いた。

\section{3. 结果}

ギャッブ長 $d=21 \mathrm{~m} 、$ ガス圧カ $p=130 T$ orrにおけるレーザ発振特性を図 2 に示す。 パルス周波数 $f_{b}$ 、放電時間 $\tau$ disは图中に示す通りである。放電電力 $W_{d}=100 k W($ 放電

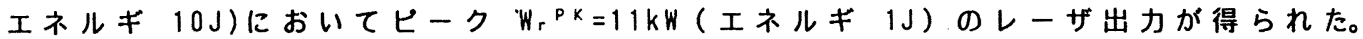

このレーザビームの集光特性を測定した結果、波動シミュレーションから予想さ れるように、サイドローブのなほほガウス状の集光特性が得られた。焦点距離 5 インチのレンズによる集光ビーム径の測定結果を図3に示す。ここで、ビーム径 $\omega$ は エアリーティスクに相当する径で定義した。図中、実線は平面波における回折限界 値である。この結果より、このビームの発散角は平面波の回折限界に匹敵すること が判明した。

参考文献 (1)葛本他:平成 2 年レーザ学会年次大会 $26 \mathrm{aV} 2$

(2)K.Yasui et.al:J.Appl.Phys.65(1),1989

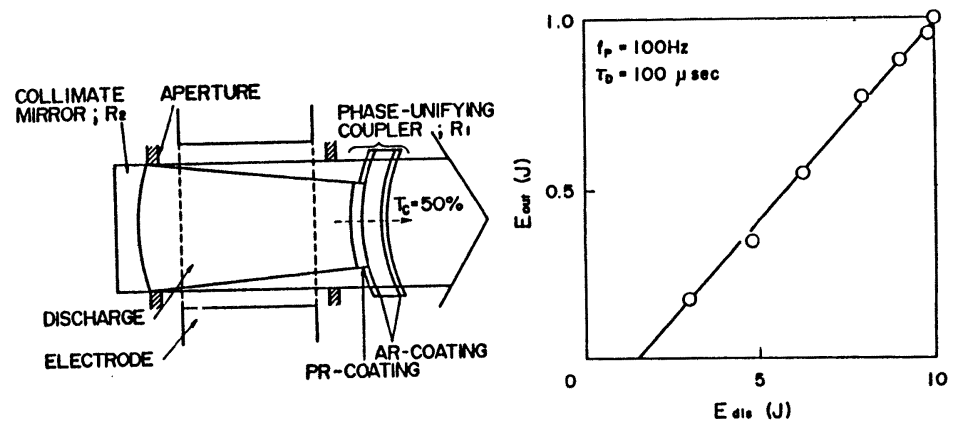

図 1 共振器構成
図 2 発振特性

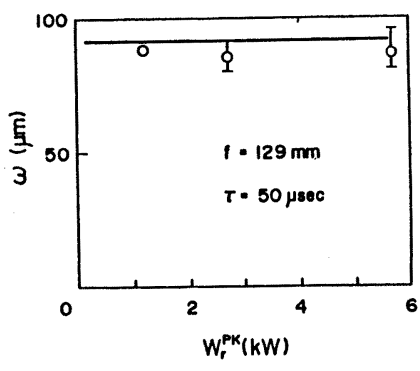

図3レーザ集光特性 
31a IV 2

負枝位相整合共振器 $\mathrm{CO}$ 2レーザ

○竹中裕司、安井公治、葛本昌樹

(三菱電機株式会社中央研究所)

1.はじめに 現在、5-10kW級の高出力 $\mathrm{CO}_{2} レ$ ー゙発振器には、正枝型の不安定型共 振器か用いられている。不安定型共振器には、正枝型の構成のほかに負枝型がる。 しかし、負枝型の不安定型共振器は、共振器内に発生するレーザビームが集光され るという性質を持つ。そのため、負枝型共振器のビーム品質は正枝型のものと比較 して劣ると予测されるため、高出力 $\mathrm{CO}_{2} レ$ オ゙発振器に用いられた例はほとんどない。 一方、負枝型共振器は正枝型のものと比較して、アライメント許容度が広い利点が あることか知られている。本講演の目的は、位相整合共振器 [1]を負枝型に構成する ことにより、負枝位相整合共振器の有用性を実証することにある。本講演では、测 定したレ、ーザ特性を報告する。

2. 共振器構成図1に共振器構成を示す。 共振器は、位相整合ミ亏一（曲率半径 3m、 中央部透過率 $50 \%$ ) と全反射ミラ一(曲率半 径 $5 \mathrm{~m}$ )を、共振器長 $3.88 \mathrm{~m}$ で負枝型に構成し ている。レーザビームは、放電励起空間で 增幅されたのち、位相整合ミラーよりビー 厶径 $45 \mathrm{~mm}$ で出射される(拡大率: $M=-1.5$ )。

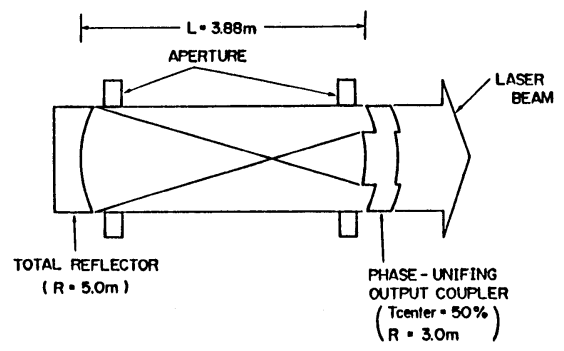

図 1 共振器構成

3. 実験結果 圀2にレーザ発振特性を示す。レーザ出力は正枝型の場合と同様 [2]、

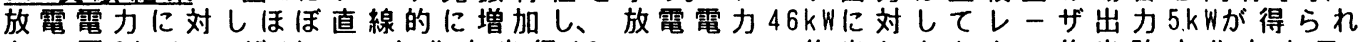

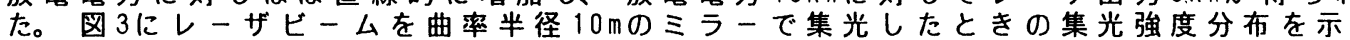
す。レーザビームの強度分布は正枝型の場合と同様、淮ガウス分布となり、高出力 域で䜿念された共振器内集光点の悪影響は観測されなかった。

4.まとめ $5 \mathrm{~kW}$ 級 $\mathrm{CO}_{2} レ$ レ゙に負枝位相整合共振器を適用した場合のレーザ特性を測 定した。得られた結果を以下にまとめる。

・レレーザ出力は放電蛋力に対しほほ直線的に增加し、5 $\mathrm{kW}$ 安定出力を得た。

- レーザビームの集光強度分布は準ガウス分布となり、共振器内集光点の悪影響は 観测されなかった。

5.あとがき 本講演では、上記測定結果のほかにアライメント許容度に関し、正枝 型共振器との比較検討結果についても報告する。

参考文献

[1] K.Yasui,M.Tanaka and S.Yagi, J.Appl.Phys. 65(1), 17(1989).

[2] S.Yagi,K.Yasui, Y.Takenaka, M.Kuzumoto and M.Tagashira, SPIE 1225, 357 $(1990)$.

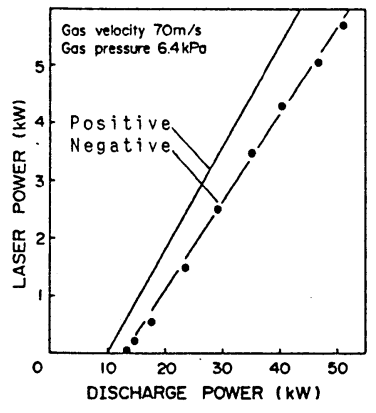

図2レーザ発振特性

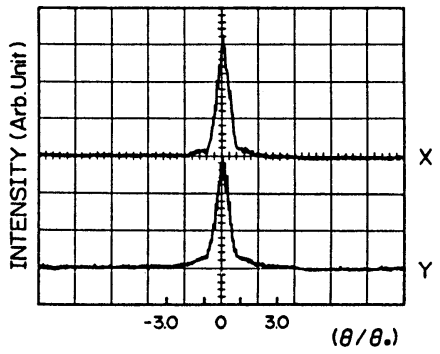

FAR-FIELD

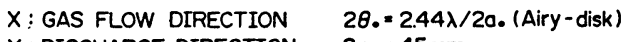
$Y$ : DISCHARGE DIRECTION $20 .=45 \mathrm{~mm}$

図3 集光強度分布 
平成 3 年レーザー学会学術講演会第11回年次大会

31 a IV 3

透過率分布ミラーをもちいた不安定型共振器におけるビーム品質の計算

安井公治

(三菱要機中央研究所)

はしめに

透過率分布ミラーを取り出しミラーに用いた不安定型共振器により大断面皘高品質ビーム が得られることが理論的、実験的に示されてきた。本講演では、透過率分布ミラーの 中央透過率とビーム品犋、共振器損失との関係、透過率分布と同時に発生する位相分 布のビーム品僙への影響について検討する。

中央透過率の影響

取り出しミラーの反射率分布は、中央から周囲へ減衰しているとしてR=Rc・o $\left(r_{1}\right)(R C$ は中央の反射率）とすると、レーザ媒質のゲインの飽和効果を入れないとき固有方程 式は光の場しとして、

$$
\begin{aligned}
U_{2}\left(r_{2}\right) & \left.=\iint \sqrt{\left(R C \rho\left(r_{1}\right)\right)} U_{1}\left(r_{1}\right)\right\}\left(r_{2}, r_{1}\right) d r_{1} \\
& \left.=\sqrt{(R C)} \iint \sqrt{\left(\rho\left(r_{1}\right)\right.} \quad U_{1}\left(r_{1}\right)\right\}\left(r_{2}, r_{1}\right) d r_{1} \\
& =\sqrt{(1-T C)} \sqrt{\left(1-T_{0}^{*}\right) U_{1}\left(r_{1}\right)}
\end{aligned}
$$

ここでT。*はミラー中央の透過率が0のときの共振器損失、 $3\left(r_{2} 、 r_{1}\right)$ はフーリエ変換を 表わす項である。式(1)より中央透過率の変化は共振器内のビームパターンに影響を与 えないことがわかる。しかし、共振器から取り出されるビームパターンには影響を与 え、従って取り出されるビームの品質は中央透過率丁cに影響されると考えられる。一 方、

$$
U_{2}\left(r_{2}\right)=\sqrt{\left(1-T^{*}\right)} U_{1}\left(r_{1}\right)
$$

と表わされるから、式(1),(2)を比較して

$$
T^{*}=\left(1-T_{0}^{*}\right) T C+T_{0}^{*}
$$

と表わされ、共振器損失厂*は中央の透過率に比例して增大することがかる。 位相分布の影響

透過率分布ミラーは、その製法から透過及び反射ビームに対して位相分布を与え、従っ て位相分布ミラーともいえる。特に、不安定型共振器に透過率分布ミラ一を用いた場 合には、位相差のビーム品質への影響は大きいと考えられ、またその度合は、中央部 分反射部と周囲透過部を通過するそれぞれのレーザ出力の比、ならびに共振器の拡大 率等に影響されると考えられる。

\section{計算結果}

ステップ状の透過率分布をもつ取り出しミラーを用いた不安定型共振器内のレーザ ビームを例にとる。中央の透過率、位相差とビーム品質との関係をまとめて图旧示 す。中央の透過率 0から $10 \%$ 程度の増加でビ 一ム品質は倍加することがかる。ここで ビーム品質は仮定した集光点でのエアリー ティスク（以下の位相差を含む場合は焦点 位置の移動を考虑した）内に含まれるレ ーザ出カで定義した。また位相差の発生 はビーム品質に大きく影響し、位相差 $\pm \pi$ で等位相の場合と比較してビーム品質 は約半分に低下した（CO2レーザ用ミラーを

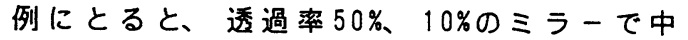
央部と周囲透過部間の位相差 $0.5 \pi 、 1.0 \pi$ 程度発生する)。高品質ビームの取り出し には位相差を補償した取り出しミラーの使 用が必要であることがわかる。

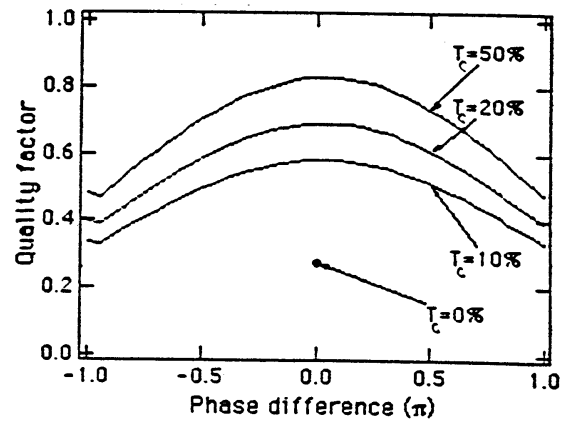

図1 ミラー中央透過率、中央部 周囲部間位相差とビーム品質 
31a IV 4 全固体素子雴源を用いた

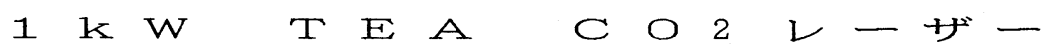
畑中秀和 ${ }^{A}$ 河原暢郎 ${ }^{A}$ 緑川克美田代英夫的原夏 ${ }^{A}$

(理化学研究所慶應義塾大学理工学部 ${ }^{A}$ )

我々は高繰り返し高平均出力 TEA CO2レーザ一の励起電源の長寿命化、高平均出力化の ために全固体素子電源（ASSE：all-solid-state exciter）の開発を行ってきた。これま でに、伝送エネルギー10J級ASSEによってTEA C 02 レーザーを励起し、繰り返し速度 $1 \mathrm{kpps}$ (pulses per second) で平均レーザー出力 250 W（総合効率：3.2\%) (1)、また100 J 級ASSE（Fig.1）によって、レーザー出カエネルギー9.1J/pulse（総合効率：8.1\%、エネ

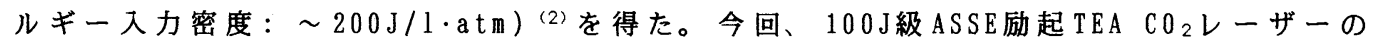
高繰り返し動作実駼を行い、140ppsで平均レーザー出力 $1.2 \mathrm{~kW}$ (総合効率： $7.6 \%$ 、エネル ギー入力密度：〜200J/1.atm) を得た (3)。(Fig.2)この時の動作条件は、レーザーガ ス $\mathrm{CO}_{2}: \mathrm{N}_{2}: \mathrm{He}=1: 1: 5$ (全圧: 1気圧)、放電部ガス流速約 $50 \mathrm{~m} / \mathrm{s}$ (大気圧空気)、放電体積 $3.0 \mathrm{~cm}$ (ガス流方向) $\times 3.3 \mathrm{~cm}$ (電極間方向) $\times 50 \mathrm{~cm}$ (光軸方向) $=500 \mathrm{~cm}^{3}$ であった。今後 綠り返し速度を一層高めマルチ kW 級 TEA C 02 レーザーを開発するにあたつて、放電入力パ ワーの增大によって高温となったガスを均一に冷却して温度の不均一分布（温度乱れ） を抑えること、及び放電によって発生する音響波をすばやく隇衰させて密度乱れを抑え ることが必要になると考えられる。そこでレーザ一主放電部上流にヒータ一を挿入し放 電部に温度 (密度) 乱れを形成し、その放電安定性等への影響をシミュレートしたので その結果についても報告する予定である(4)。

References

(1) H.Hatanaka et al., J.Appl.Phys. 68, 1456 (1990).

(2) H.Tanaka et a 1., Rev.Sci.Instrum. 61, 2092 (1990).

(3) H.Hatanaka et al., in Proceedings of Eighth International Symposium on

Gas Flow and Chemical Lasers, (SPIE,Bellingham,WA), Vol.1397, paper ThP5, (in press).

(4) V.Yu.Baranov et al., Sov.J.Quantum Electron. 10, 1512 (1980).

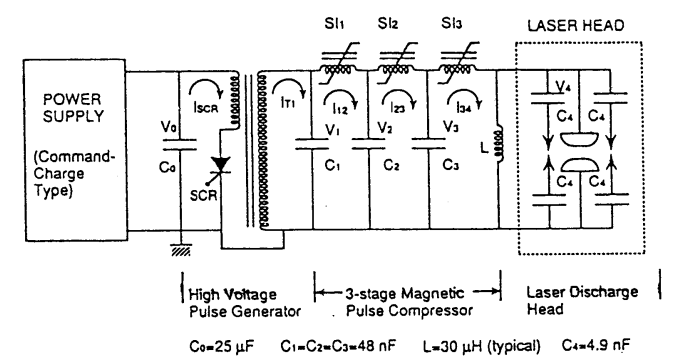

Fig.1 Electrical circuit of a TEA $\mathrm{CO}_{2}$ laser with an all-solid-state exciter.

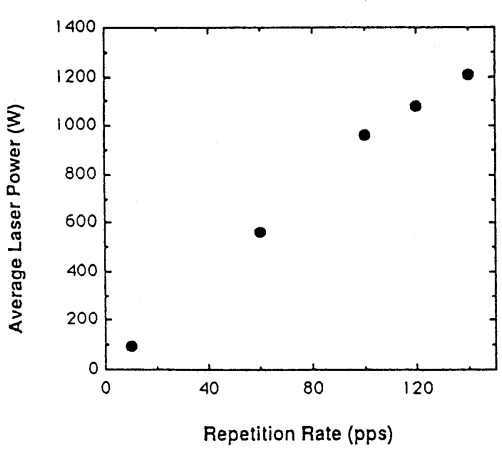

Fig.2 Dependence of average $\mathrm{CO}_{2}$ laser power on the pulse repetition rate. The stored energy in the primary capacitor $\mathrm{C}_{0}$ was $113 \mathrm{~J}$. 


\section{1a IV 5 閉サイク ル T E A C O のガス再生条件}

。外園博一 小林直樹小原曾（慶應義塾大学）

\section{1. まえがき}

C Oュレーザーでは、励起放電中の電子街突によって発振媒体であるCOュ分子が相 当量破塤されるため、その閉サイクル運転時には適当ながス再生装置が必要不可欠で

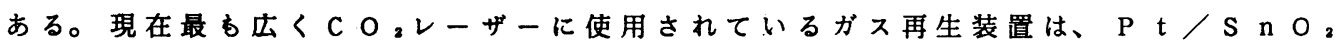
等の固体触媒を用いて、分解生成物の $\mathrm{C} O$ 及び $\mathrm{O}_{2}$ を $\mathrm{CO}$ に変換するタイブのるので ある。しかしながら現在、これら固体触媒ガス再生装置の技術開発レベルは、高出力 T E A C Oュレーザーの長時間安定、閉サイクル動作を実現するには未だ到っていない と考えられる。そこで、今回我々は、詳細な理論モデルを用いて、TEACOュレーザ 一の長時間安定動作に必要なガス再生条件を明かにすることにより、これらガス再生 装置の開発、設計指針を得るための研究を行った。

2. 理論モデル及び計算結果

我々の使用した理論モデルは、TEACOュレーザーの閉サイクル運転時のガス組成 及びレーザー出力の变化を模擬できる開発济みの理論モデル(1)に、新たにガス再生装 置をモデル化して組み込んだるのである。一般に固体触媒では、分解生成物である化 学量論相当数の $\mathrm{C} O$ 及び $\mathrm{O}_{2}$ が一次反応に従って $\mathrm{CO} \mathrm{2}_{2}$ 变換されるすのと近似できる。 したがって、この理論モデルでは、ガス再生装置流入前の $\mathrm{C} O$ （叉は $\mathrm{O}_{2}$ ）濃度に対し・ て、通過後にCO 再生装置の性能を評価するすのとした。図1には、クリアランス比3、入力エネルギ 一密度 $1922 \mathrm{~J} / 1$ の場合の、絽り返しショット数に対するレーザーエネルギーの変 化を、变換効率をパラメータとし て計算した結果を示す。図から明 かな通り、ほぼ变換効率 0.3 以上 において当初レーザーエネルギー の約 $98 \%$ 以上の出力エネルギー が維持されている事がわかる。長 時間安定な出力を維持するのに必 要な変換効率は、クリアランス比、 入力エネルギー密度に依存するす のと考えられる。これらの計算結 果については、当日報告する。 (1) H. Hokazono and M. Obara, Appl. Phys. Lett. vol.57, p4 (1990)

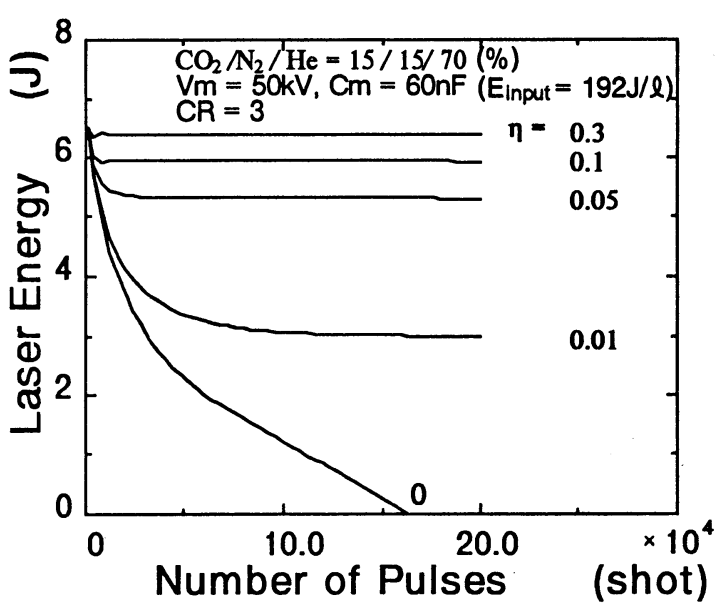

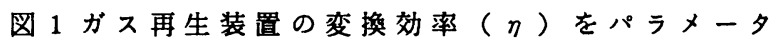
とした時のショット数に対するレーザーエネルギ 一の变化。 
平成 3 年レーザー学会学術講演会第11回年次大会

31a IV 6

$$
\text { シーケンスバンドCWCO } 2 \text { レーザの動特性 }
$$

○志水裕一 土志田 実^片田毅^

（川崎重工業株式会社 岐皁工場 $\mathrm{A}$ 防衛庁 飯岡支所）

I .はじめに

通常のCOュレーザは、レギュラーバンドと呼ばれる

$\left(\begin{array}{lll}0 & 0 & 1\end{array}\right)-\left(\begin{array}{lll}1 & 0 & 0\end{array}\right)$ 準位間でレーザ発振が起こる。

しかし、レギュラーバンドよりすエネルギー的に 1 モー

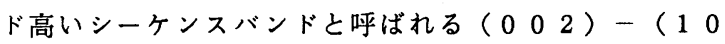

1) 準位間ですレーザ発振が可能である(図 1 参照)。

このバンドにおけるレーザ光を励起光源にすれば、

$\left(\begin{array}{lll}1 & 0 & 1\end{array}\right)-\left(\begin{array}{lll}1 & 0 & 0\end{array}\right)$ 準位間における $4.3 \mu \mathrm{m}$ のレ

一ザ光を得ることが出来る。この $4.3 \mu \mathrm{m}$ のレーザ光

発振への 1 ステップとして、シーケンスバンドの動特性

を明らかにしたので報告する。

\section{II . 実験内容及び実験装置}

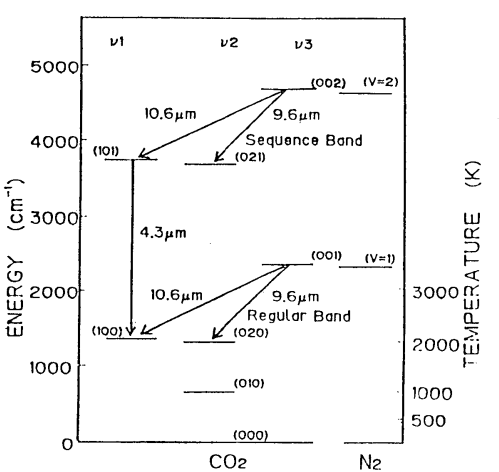

図1振動エネルギー準位図

シーケンスバンドにおけるレーザ発振を実現するためには、レギュラーバンドにおける発 振を抑制する必要がある。そこで、レギュラーバンドを吸収させるために共振器内にホット セルを挿入した。製作した実験装置の概要図を図 2 に示す。このホットセルは高温の $\mathrm{CO}_{2}$ ガ スを封入した石英管で加熱・保温のためのバン ドヒータ及びグラスゥールが巻き付けてある。 また、シーケンスバンドの利得は小さいと考え られるので、グレーティングの損失を補うため に共振器の反射鏡側には部分反射鏡とグレーテ GRATNG ィングで構成された複合共振器を使用した。

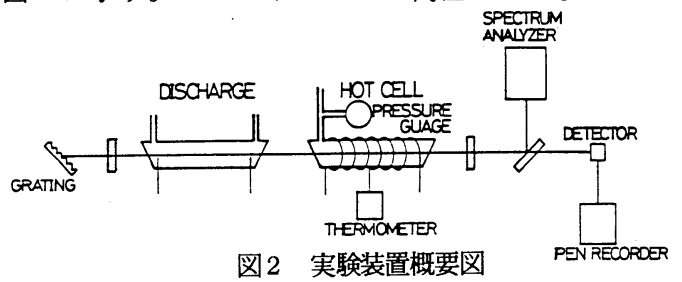

\section{III. 実験結果}

ホットセルの $\mathrm{CO}_{2}$ ガス圧力に対する出力を図 3 に示す。 $\mathrm{CO}_{2}$ ガス压力を増していくと、

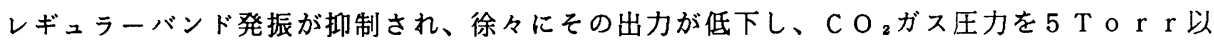
上にすると、シーケンスバンド発振に移り変わった。

レギュラーバンドとシーケンスバンドの各発振線毎の小信号利得を図 4 に示す。シーケン スバンドの小信号利得 (図4 下部) は、レギュラーバンドの小信号利得 (図 4 上部) と同様 な並進温度のゲイン分布を持ち、レーザ管の静圧 $15 \mathrm{~T}$ 。 r r、放電電流 $20 \mathrm{~mA}$ の時、 発振線 P ( 21 1) において、約 $0.32 \% \mathrm{c} \mathrm{m}^{-1}$ であった。

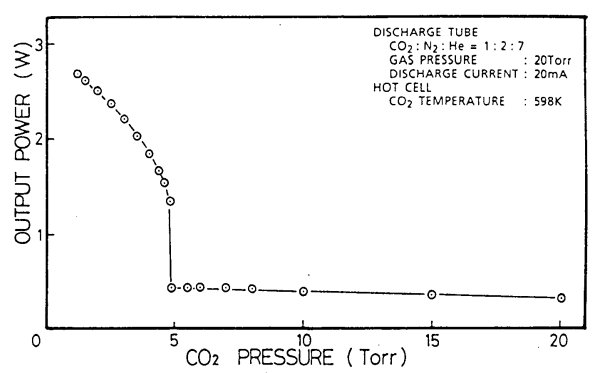

図3 $\mathrm{CO}_{2}$ ガスに対するシーケンスバンド出力

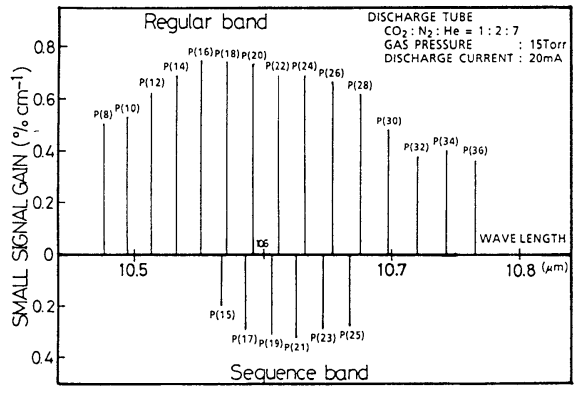

図4 小信号利得 


\section{1a IV 7 円形アレイ導波形炭酸ガスレーザー}

\section{三木弘次郎 松島朋史 末田正 （大阪大・基礎工）}

はじめに 尊波形炭酸ガスレーザーの出力をあげる方法 としては、咅波路を数本並べ、それぞれの尊波路間に陵 間を設けフェーズロックアレイレーザーを構成すること が考えられる。現在、尊波形炭酸ガスレーザーアレイと して、導波路を直線状に並べたものが報告されている1” 2)。しかしこの場合、導波路数が增えると一様なつエー ズロック動作が起こりにくくなる欠点が考えられる。そ こで我々は、この欠点を補うために、導波路を内状に並 ベた円形アレイレーザーを提案する（図 1 )。

実験及び結果 今回は予備実験として、円形アレイレー ザーの一部分（2本の寘波路）を作製し（図 2 ）、その

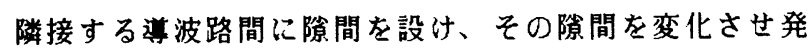
振動作を行った。そして、フェーズロック動作が行われ る条件を見つけるため、次の実験を行った。

ビニ上周波数及ざ遠視野像の観則，吵間が狭いと（実験 值: $0.3 \mathrm{~mm}$ ）、独立な 2 本の並波路となり、互いに干涉し ない2つのレーザが存在し、それぞれのレーザの発振周 波数の差（ビート周波数）が観测された。

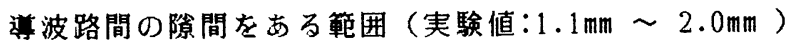
にすると、ビート周波数は観測されない。また、近視野 では 2 つのビームスポットが観測されるが（図３）、遠 視野ではビームスポットは1つに集束した（図４）。こ の場合フエーズロック動作が行われていると考えられる。

これより隙間を広げると（実験值: $2.75 \mathrm{~mm}$ )、もはや 2 本の導波路として存せずに、高次モードが発生して、 遠視野でも2つのビームスポットが観测された。

まとめ 以上の結果より、萁波路間の隙間が適当な場 合、フェーズロック動作が起こることが確認された。こ れより、円形アレイレーザーの実現が可能と考えられる。 参考文献

1)L.A.Newman et al.:App1.Phys.Lett.48.(1986).

2)R.A.Hart et al. :Appl.Phys.Lett.51.(1987).

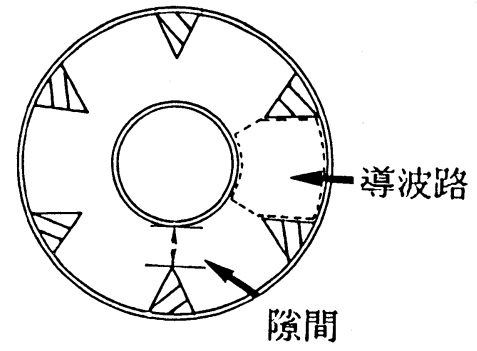

図 1 円形アレイレーザー断面図

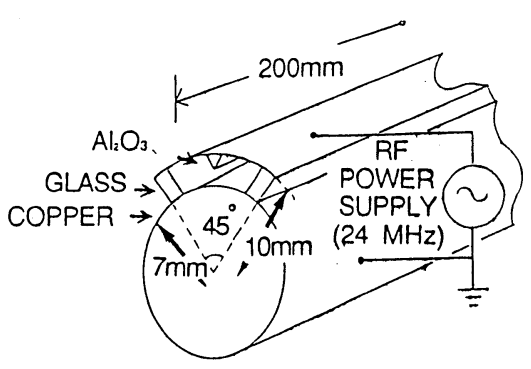

図 2 レーザー構成図

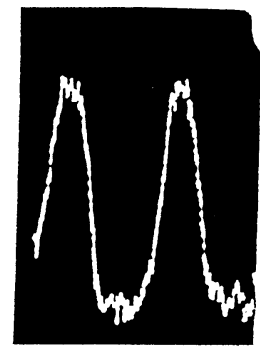

图3近視野における

レーザー出力光の強度分布

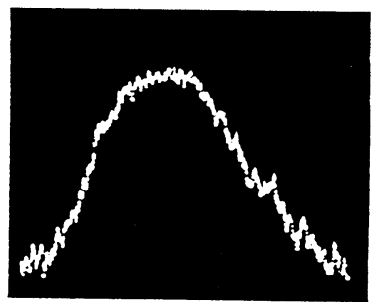

図4遠視野における

レーザー出力光の強度分布 


\section{平成 3 年レーザー学会学術講演会第 11 回年次大会}

31a IV 8 マイクロ波放電励起 C O 2 レーザの開発

- 西前㮌一、吉沢慧治、熊本健二*、八木重典 * (三菱电機株式会社 中央研究所、名古屋製作所 ${ }^{*}$ )

\section{1.まえがき}

マイクロ波放電は、高電力密度かつ安定な放電が可能であること、無電極放電であ り電極に起因する問題が無いことなどの特長を有するため、様々な放電励起レーザへ の適用か試みられている1・2。今回、均一なマイクロ波放電を発生する放電装置を用い、 小形のCOュレーザを開発したので報告する。

\section{2. 実顥装置図1に装置の断} 面を示す。放電空間は金属体に設 けられた溝をセラミック板で蓋う ことにより構成される。マイクロ 波パワーは導波管から結合空を経 て、セラミック板に沿つて導入さ れ、セラミック板表面に垂直な電 界を形成する。図2に今回用い た共振器の構成を示す。放空間 の狭い方向に対しては迸波路型の

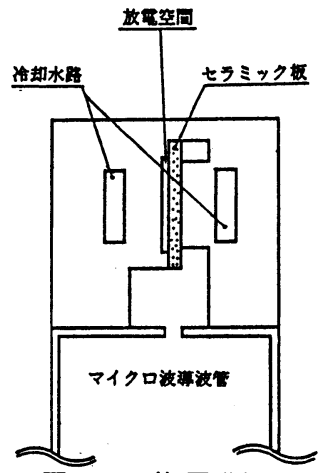

图1。装置断面
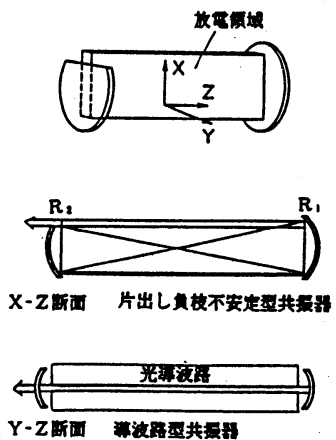

図 2. 共振器構成 共振器、広い方向に対しては of $f$ -axis の負枝不安定型共振器として動作するハイブリッド共振器である。

3.実娩結果困了にマグネトロンをパルス動作させたときの発振波形を示す。ヒ 一ク出力 $1 \mathrm{~kW}$ 、立ち上がり $20 \mu \mathrm{s}$ のパルス出力が得られている。またcw発振させ た場合の平均出力としては、放電長 $400 \mathrm{~mm} て ゙ 6 \mathrm{~W}$ が得られた。

図4に出力ビームの不安定側と導波路側の発散角の比率と不安定型共振器の㧨大 率（M值）との関係を示す示す。M值を選択することにより出カビーム形状を制御でき ることが示される。 $M=1.075$ においてほぼ軸対称の遠視野分布を持つ出カビームが得 られたここのビームはガウス状の分布を有し、回折限界の菓束性を示した。

[1] K.G.Handy,J.E.Brandelik, J.Apple.Phys., Vol.49, N0.7, July(1978)

[2] P.J.K.Wisoff,et al, IEEE J.Quant.Elec., Vol.QE-18, N0.11, Nov.(1982)

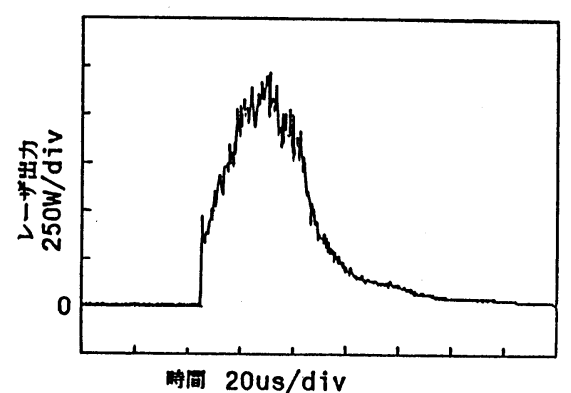

図3.パルス発振波形

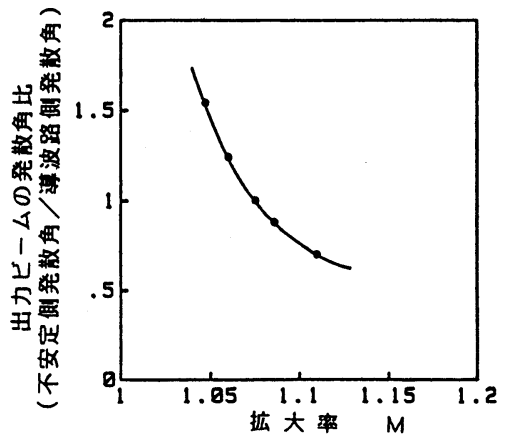

図4.ビーム形状とM值の関係 
平成 3 年レーザー学会学術講演会第11回年次大会

31a IV 9

\author{
橫方向 R F 放電励 起 \\ C Oレーザーの懪礎特性 \\ 一小方大成, 鎌上則夫・, 谷脇学・, 佐藤俊一 $\cdots$ \\ (日本工業大学, 一東京電機大学, 一産業創造研究所)
}

1.はじめに

$\mathrm{R} F$ 放電は、均一な高密度励起か達成できる、放電安定化（バラスト）抵抗か不用なた めシステムを効率化，簡素化できる、誘電体電極の使用により電極へのスパッタリングの 閏題をなくすことができる等の特長を有し、C O 一から高出力の産業用レーザーまで広く適用されている。今回我々は $\mathrm{R} F$ 放電を横方向励 起C ○レーザーに適用し、その基硽特性を調べたのでここに報告する。

\title{
2. 実跧装置
}

本実馱装置の仕㥞と実踰条件 をTable.1に示す。放䉓部は循環 環型低温風洞に組み込まれており $\mathrm{R} F$ 䉓力は逆 L 型の整合回路を経 て負荷に供給される。ガス組成は D C 放筆励起の埸合(1) と同様と した。共振器には、反射率 $95 \%$ の $\mathrm{ZnS}$ e平面ミラ一と曲率半径 $10 \mathrm{~m}$ の Cu基板 $\mathrm{Au}$ uート凹面ミ ラ一を用いた。

Table.1 R F 放電励起 C Oレーザーの仕様と実験条件

\begin{tabular}{|c|c|c|c|}
\hline 型 & & 式 & 横方向流横方向励起型 \\
\hline $\mathrm{R}$ & $\mathrm{F}$ 周 波 & 数 & $13.56[\mathrm{MHz}]$ \\
\hline 電 & 極 材 & 料 & アルミナ \\
\hline 放 & 電 体 & 積 & $2^{\mathrm{H}} \times 3^{\mathrm{W}} \times 35.5^{\mathrm{L}}=213 \mathrm{~cm}^{3}$ \\
\hline カ & 又 組 & 成 & $\mathrm{CO} / \mathrm{N}_{2} / \mathrm{He} / \mathrm{O}_{2}=6 / 16 / 78 / 0.2[\mathrm{~mol} \cdot \%]$ \\
\hline 力 & ス圧 & 力 & $30 \sim 50[$ Torr $]$ \\
\hline ガ & ス 温 & 度 & $150 \sim 210[K]$ \\
\hline 共 & 振 & 器 & 単一光路安定型共振器 \\
\hline
\end{tabular}

\section{3. 実験結果}

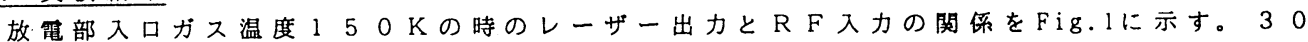
$\mathrm{T} \circ \mathrm{r} \mathrm{r}$ のとき出力の跑和がみられるのに対し、4 $0 \mathrm{~T} \circ \mathrm{r} \mathrm{r}$ 以上では出力はほほ線形に

增大している。 $40 \mathrm{~T} \circ \mathrm{r} \mathrm{r}$

のとき入力 $3.2 \mathrm{~kW}$ (入力

密度 $\left.15 \mathrm{~W} / \mathrm{c} \mathrm{m}^{3}\right)$ で出力

$570 \mathrm{~W}$ が得られている(電

気変換効率1 7 . $8 \%$ ）。放

電は光軸方向に若干の不均一

性を生じているが実験の範囲

で放電の不安定化や $\alpha$ 放電か

ら $\gamma$ 放電への移行(2) は観测

されなかった。近視野に於け るビームパターン、連続動作 時の出力安定度等についても 調べた。

参考文献

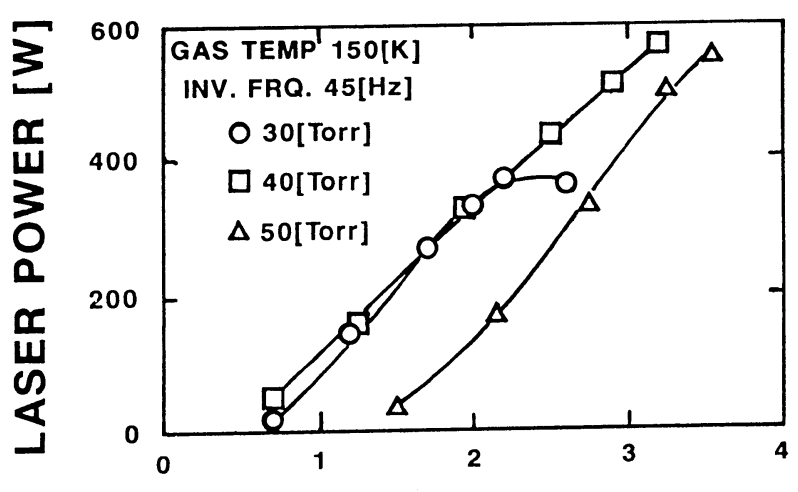

\section{RF INPUT POWER [kW]}

F i g.1 1 レーザー出力とRF入力の関係

(1) S. Sato et a1., J.Appl. Phys.58,3991(1985).

(2) D.R.Hall and H.J.Baker , SPIE.1031,60 (1988). 
31a IV10

加工機朋よう素レーザの開発

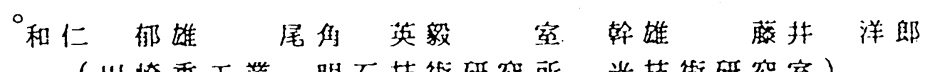

(川㥓重工業明石技術研究所兆技術研究空)

(はじめに】よう素レーザはその発振波長が1.3 $3 \mu \mathrm{m}$ と短く、金属表面で吸収さ れやすいこと、さらに石英系光ファイバーの最低透過損失領域にある、など加工機と して传れた特徽があ。当社では、よう素レーザの実用化研究を行い出力 $1 \mathrm{~kW}$ 、安

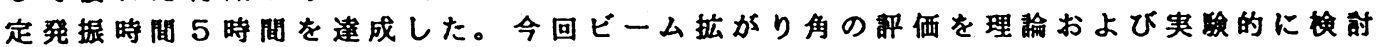
したのでこれを報告する。

【ビーム拡がり角の理論式】一共层器のモード理論より得られる高次のエルミートカ ウシアンビームを外指して、ビームの㹡がり角に関する以下の简略式が得られる（但 し、半透過鏡の曲率は必)。

$$
\theta=2 \mathrm{a} / \sqrt{\mathrm{L}(\mathrm{R}-\mathrm{L})}
$$

$$
\begin{aligned}
& \theta \text { : ビーム㹡がり角。2 } \mathrm{a} \text { : ビームウェストのビーム径。 }
\end{aligned}
$$

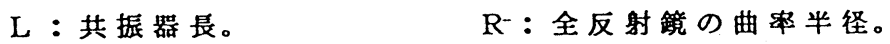

【実跧置】 $1 \mathrm{k} \mathrm{W}$ 級加工機用よう素レーザテスト機（図1）を使用し、ビーム㹡 がり角計测系には収差の尉然を抑えるため長焦点（ $f=800 \mathrm{~mm} ）$ のレンスを用い、 焦黾素子アレイ（ＳＰＩＲＩＣＯN社㹕）およびアクリルバーンパターンの焦点スポ ット径にて揤定した。

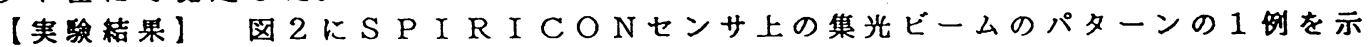
す。このパターンから得られたビーム拡がり角とアクリルバーンパターンから得られ たビーム径を用いて前記の簡略式の有効性を確認した（図3）。

【あとがき】簡略式の有効性を確認できたことにより、図4のレーザ出力と取り出 しビーム径の関作を剆定することで、任意のレーザ出力、任意の共振器曲率半径に対 するビーム拡がり角を評価することが可能になつた。

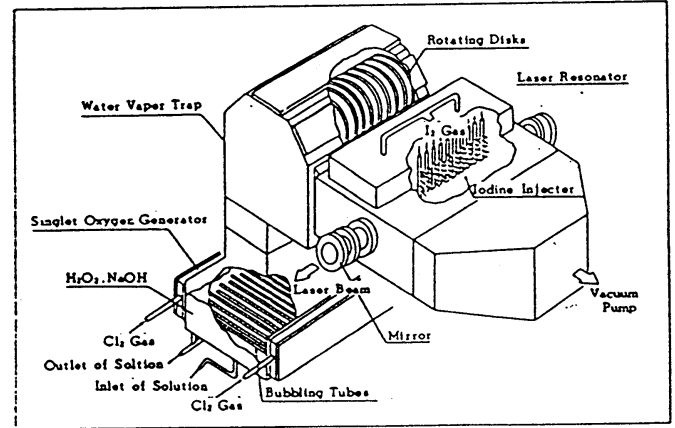

図1よう素レーザ略图

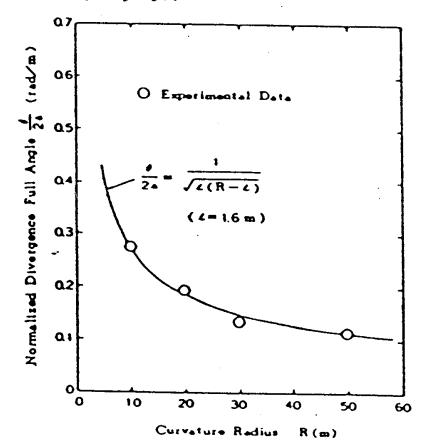

図3ビーム㹡がり鿇揤定結果

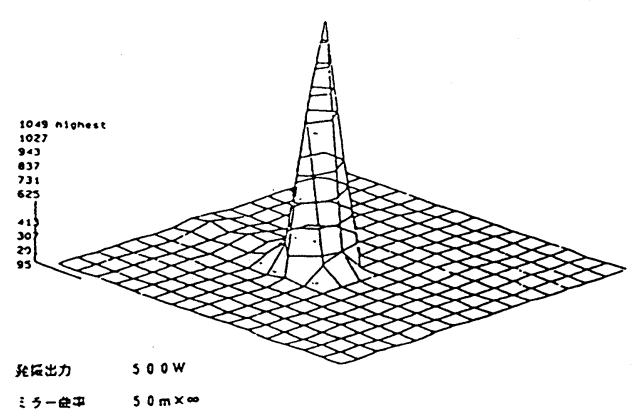

図 2 焦点面のビームパターン

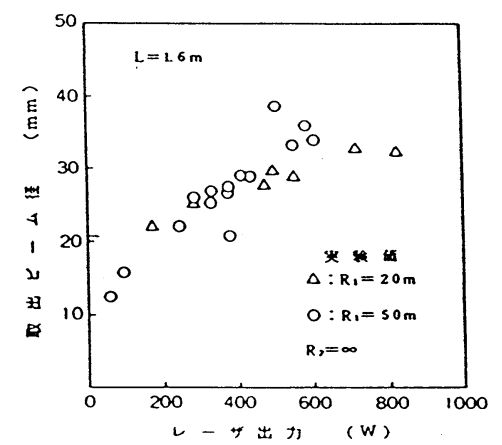

図4取り出しビーム径揤定結果 
31 a IV11

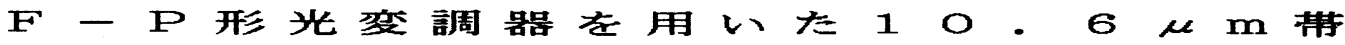
周 波 数 要 換

大阪大学基礎工学部松島朋史中尾雅俊末田正

炭酸ガスレーザーは $10.6 \mu$ 帯コヒーレント光を効事よくまた大出力で取り出す ことができるため, 広笻囲な応用が考えられる。その中でも，分光学，エネルギー問 題に関連して注目されている同位体分離, レーザーレータによる大気污染の観㓻, 赤 外光を用いた通信・計測等の応用に祭しては，レーザー光の波長（周波数）を精度よ く，铰細にかつ安定に変化できることが重要である。

$10.6 \mu$ 光光の周波数変換には，高圧カレーザーをはじめ種々の方法が考えられるが， 電気光学効果を利用した变調器を用いる方法は, 電気的に, 高い精度で, かつ安定に 波長（周波数）変化させることができるという特長を持っている.しかし，電気光学 効果は波長に逆比例するため, 炭酸ガスレーザー光のような長波長帯において十分な 周波数変換出力を得るには，非常に大きな变調電力が必要となる，従って，低電力化 を計り，高効率周波数変換器を設計するには何等かの工夫が必要となる.

我々は光波の多重反射によって高い変換効率が得られる $\mathrm{F}-\mathrm{P}$ 形光変調器を利用す ると共に，光波と変調波に円偏波を用い，ただ一つの㑡波帯成分のみ発生させること により高効率化を図った $\mathrm{F}-\mathrm{P}$ 形周波数変換器を考案した。この変調器はもう一つの 特徵として, $F-P$ 形光変調器の出力側ミラーに複合ミラー（ 2 枚のミラーで構成） を用いている。これによって，搬送波に対しては $100 \%$ の反射率，㑡波帯に対しては 最適な反射率をもたせることにより，周波数変換効率の向上を計っている。

図 1 は変調器の構成図を示す。図2 2 は 計算例を示す。ここでは，結晶に $\mathrm{CdTe}$ ( $4 \times 4 \times 20 \mathrm{~mm}$ ，バルク吸収係数 $0.001 \mathrm{~cm}^{-1}$ ) を用い, 複合ミラーの搬送波に対して反 射率を $100 \%$ ，側波帯に対する反射率を パラメータにし，位相变調指数に対する 側波帯出力と入射光強度の比を求めた。 点線は $\mathrm{F}-\mathrm{P}$ 形構成を用いない場合 ${ }^{11}$, 実線は $\mathrm{F}-\mathrm{P}$ 形構成の出力側ミラーに複 合ミラーを用いた場合である。

これより，提案した $\mathrm{F}-\mathrm{P}$ 形構成にす ることにより, 高効率な周波数変換器の 実現が期待できる。

1) Buhrer,et al Apll. Phys.Lett., Vol.1, $0 \mathrm{ct} .1962$.

2) 中尾, 松島, 末田: 1988 春期応物関連

予稿 (31aZN5)

3 )松島, 末田: 輻射科学研究会 RS 89-3,1989
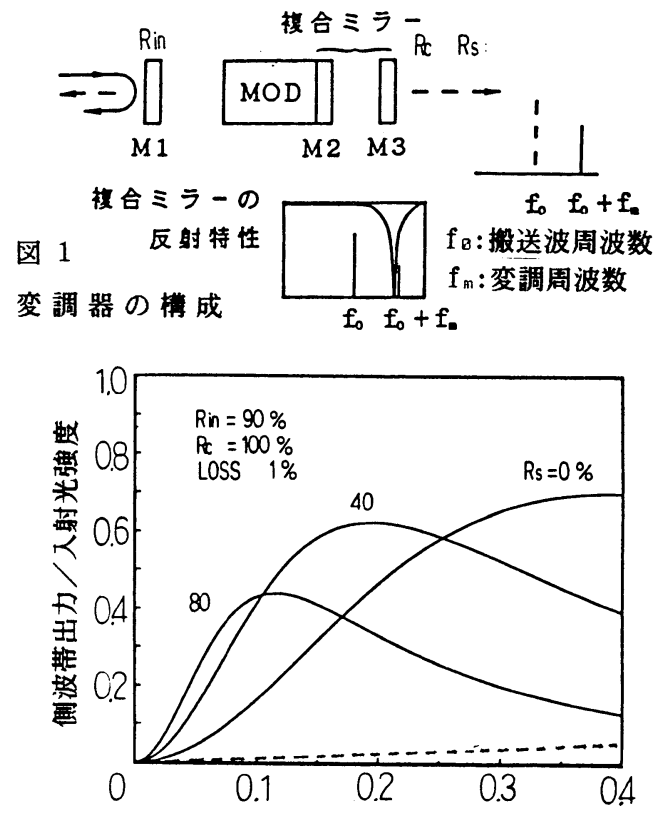

図 2

位相变調指数に対する側波帯出力と入射強度の比 
31 a V 1

\section{固体化電源を用いた 100 W銅蒸気レーザーの発振特性 Characteristic of $100 \mathrm{~W} \mathrm{CVL}$ pumped by all solid state exciter}

竹田哲也 出口博史 ${ }^{* *}$ 藤原閲夫 ${ }^{*}$ 井澤靖和 ${ }^{*}$ 中井貞雄 ${ }^{*}$ 山中千代衛 (レーザー総研、阪大レーザー研*、関西電力**)

銅蒸気レーザー（CＶＬ）は、レーザー同位体分離の主要なレーザーとして注目されて いる。

しかしながら従来から用いられてきたサイラトロンスイッチは高価な上、寿命も千時間程 度と短く高繰り返し化、及び高出力化への大きな障害となっていた。

我々は、銅蒸気レーザー電源の長寿命化を目的とし、S I サイリスタと、2 段の磁気パ ルス圧縮回路を用いて銅蒸気レーザー用固体化電源の開発を行ってきた。これまでに繰り 返し $5 \mathrm{k} \mathrm{H} \mathrm{z}$ でレーザー出力 $1.03 \mathrm{~W}$ 、短パルス発生のための電源効率として、最大 84 \%が得られている。また可飽和リアクトルのリセット電流を調整することで、2 倍以上に おける幅広い入力エネルギーに対して電源効率を落とすことなく運転可能であることを示 した。また、固体化電源を用いた銅蒸気レーザーの同期ジッターを士 $2 \mathrm{n} \mathrm{s} に$ 抑制でき、 同位体分離システムに導入可能なこともわかった。

本報告では、100 W級固体化電源（P A L D EN-II 号）を製作し高効率高出力化を 図り、電源特性及びレーザー特性を測定したのでその結果について報告する。

図 1 は固体化電源（P A L D E N-II号）の回路図を示す。磁気パルス圧縮回路におい てはシミュレーションコードにより最適化を行うと共にS I サイリスタの損失を減らし高 効率化を図っている。得られた結果を表 1 にまとめる。

尚、本研究は（株）東洋電機製造、及び（株）関西電力総合研究所、（財）レーザー技 術総合研究所との、共同研究によるものである。

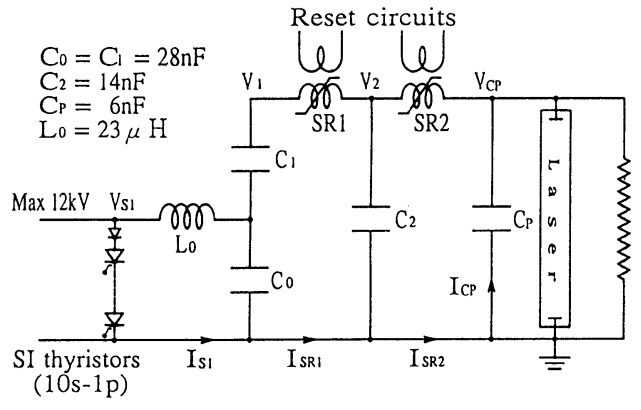

表1 $20 \mathrm{~W} \& 100 \mathrm{~W}$ ClL with all solid state exciters have been developed.

\begin{tabular}{|l|c|c|}
\hline & PALDEN- I & PALDEN- II \\
\hline Maximum charging voltage $(\mathrm{kV})$ & 4 & 12 \\
\hline Number of semiconductors & 8 & 10 \\
\hline Average switching power( $\mathrm{kW})$ & 8 & 20 \\
\hline Repetition rate $(\mathrm{kHz})$ & 5 & 5 \\
\hline Overall switching efficiency $(\%)$ & 67 (Max.) & 84 (Max.) \\
\hline Avcrage CVL output power $(\mathrm{W})$ & 28 & 103 \\
\hline
\end{tabular}

国 PALDEN.I Circuits of 20kW all solid state exciter for 10OW CYL 
渡, 辺郁男、林和夫、野田说夫、跲木節陫、小川朋子、井関康、森宮修

(株式会社東芝総合研究所)

銅蒸気レーザは原子法レーザウラン同位体分離に用いられており、現在その大ロ经 化が求められている。今回、口径 $80 \mathrm{mm、}$ 放電長 $1500 \mathrm{~mm}$ 銅蒸気レーザにおいて、充電 電压、バッファガス压、レーザ管壁温度を独立に変化させて、レーザ出力、電力投入 好染（電䃇出力に対しプラズマに投入される電力の比）のこれらのパラメー夕依存性 を調へた。

放電管に加わる電圧の蓄積コンテンサ充電電圧依存性を図1に示す。充電電圧の增 加にともない放電電流は增加するが、放電管電压は克電電压に関係なくほぼ一定で定

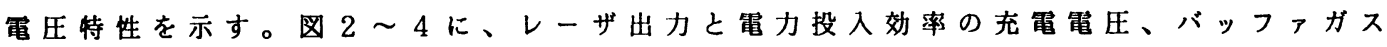
压、壁温度依存性を示す。レーザ州力の点からは、充電電生は高いほうが、バッフ ガス代は低いほうが、壁温度は1450度付近が好ましい。しかしどのパラメータに対し ても、レーザ出力が高くなる領域では霆力投入効率は低下する。

なお、本装置を用い、安定型共振器を組み発振実殹を行ったところ、空間的にフラ ットな発振パターンが得られ、最大出力 108 を得た。

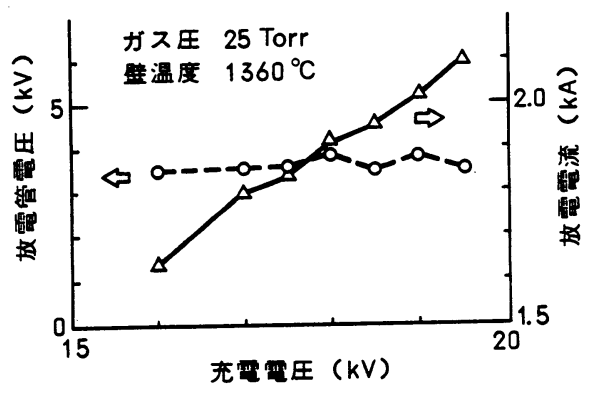

図 1 放管国压放而流の 充酶压依存性

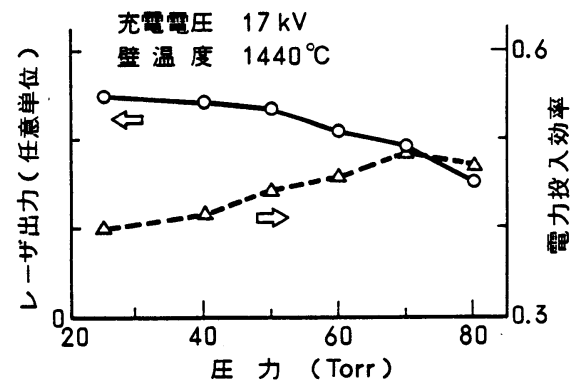

図3レーザ出カと定力投入効率の バッファガス圧依存性

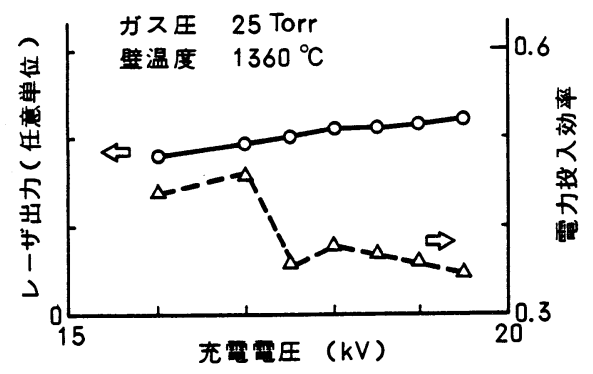

図2レーザ出力と里力投入効率の 充金管圧依存性

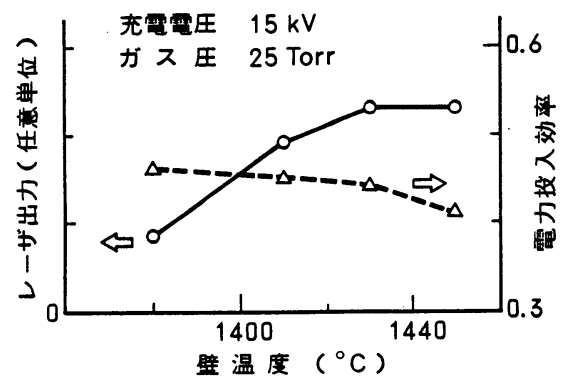

図4レーザ出力と電力投入効率の 壁温度依存性 
$31 \mathrm{a} V 3$ 銅丞気レーザービームの亩品仳

○小林德康、木村博信、小長井主群、白山新平、宫沢竜雄、高橋知幸

（東芝原子力技術研究所、ヘレーザー泿縮技術研究組合）

\section{1.はじめに}

原子レーサー法ウラン䈨縮で利用される銅蒸気レーサー（CVL）の増幅システム (Master 0scillator Power Amplifier) では C V L 初段発掁器のヒームクォリティを 向上することがシステム大出力化・高効率化の重要なポイントとなる。ここでは、 C V L 発振器レーサーヒームの高品夏化を実施し、得られた成果について報告する。

\section{2. 銅蒸気レーサー発振器と共振器光学系}

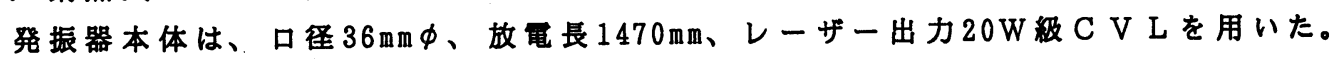
共振器光学系構成は四1に示す様に、2台のC V L 発振器を用いマスター発振器の A S E 成分を除去できるインジェクションロック方式とした。また、これは表面反射

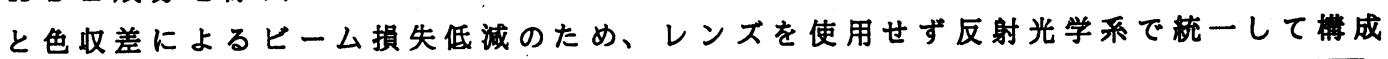
した。

\section{3 . 試験結果}

因 2 は、この共振器光学系を用いて行った C V L 発振器ビームのダイバージェンス特性 の测定結果である。また、四 3 は、この波形 テータを計算処理して求めたレーザー出力の ビーム広がり角成分依存性である。この結果、 本発振器のビームクォリティとして、 $0.3 \mathrm{mrad}$ 全角成分（回折限界の 8.6 倍）で $80 \%$ レーザ 一出力を得られることが確認された。

現在さらに高品筫化を目指し、より小口径 $(20 \mathrm{~mm} \phi) \mathrm{C} \mathrm{V} \mathrm{L}$ を用い、発振パルス幅の拡 大を目的として放電回路形態の改良を行うと ともに、共振器を短縮した光学系で同様の評 価試験を行っている。

ビーム强度

$14.5 \mathrm{~W}$

(全角成分)

(TOTAL beam)

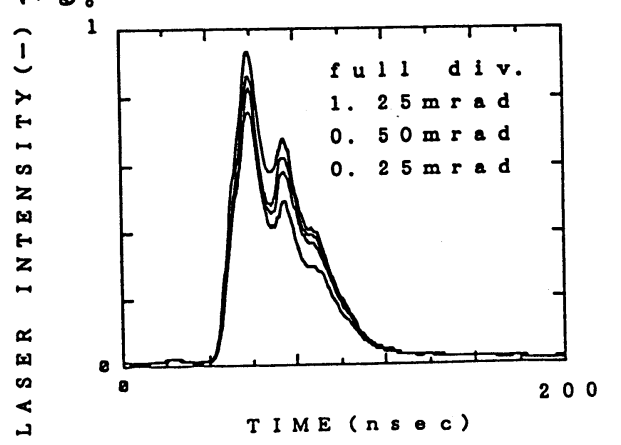

因2ヒームタイパージェンス特生

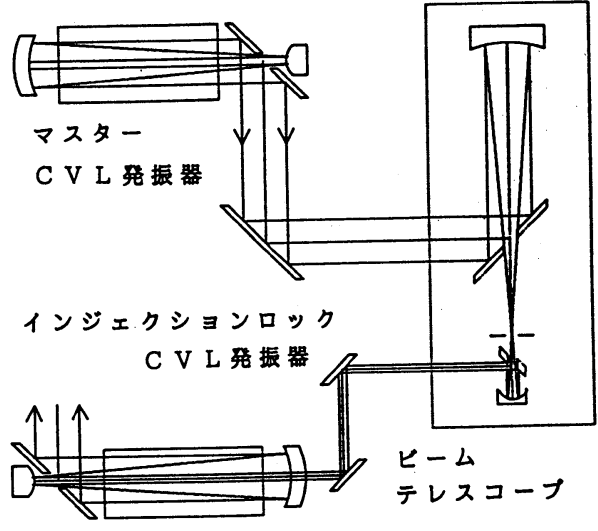

图 1 共振器光学系槽成因

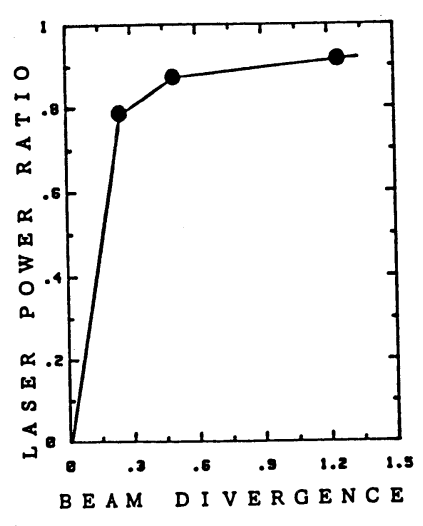

四3レーサー出カの

$(\mathrm{m} r \mathrm{~d})$

ヒーム広がり角成分依存性 


\section{$31 \mathrm{a} V 4$ 大出力銅蒸気レーザー増幅器の開発}

青木延忠, 大谷良一, 木村博信, 小長井主税, 白山新平, 宮沢竜雄（東芝原子力研）

1.はじめに

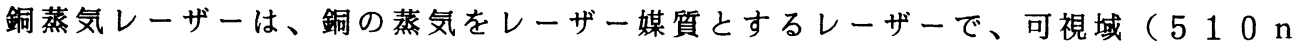
$\mathrm{m}$ 緑色と $578 \mathrm{~nm}$ 黄色）で発振する高出力・高効率・高絽り返し可能な放電型のパ ルスレーザーである。このレーザーは原子レーザー法ウラン濃縮に使用されるものと して諸外国において技術開発が推進されている。このたび銅蒸気レーザー増幅器の大 出力化開発を実施したのでここに報告する。

2. 大出力銅蒸気レーザー增幅器

図 1 に開発した銅蒸気レーザーの構造図を示す。レーザー管の両端に設けた電極間 に高電圧パルス（電圧ピーク〜2 $5 \mathrm{k} \mathrm{V}$, 電流ピーク〜2 k A ）を畉加し、レーザー 管内にパルス放電を起こして、管内温度を $1450 \sim 1500{ }^{\circ} \mathrm{C}$ まで上昇させ、銅を 蒸発させると同時に、銅原子を励起・発振させる。レーザー管は保温のため断熱材で 覆われており、その外周を水冷ジャケットで冷却する。

この銅蒸気レーザーの大出力化に関しては、レーザ 一管の熱設計及び電気回路設計にコンピュータ解析を 駆使し、有効放電体積增加のための設計に反映した。

この結果、銅蒸気レーザーの発振出力は放電長の増 加とともに直線的に増加し、口径 $60 \mathrm{~mm}$ 放電長 $3 \mathrm{~m}$ の レーザー管で単機発振出力として $211 \mathrm{~W}$ が得られた。 その結果を図 2 に示す。一方放電長 $2.5 \mathrm{~m}, 3 \mathrm{~m}$ の レーザー管の增幅特性を計った結果を図 3 に示す。こ れをもとに、放電長 $2 \mathrm{~m}, 2.5 \mathrm{~m}, 3 \mathrm{~m}$ の銅蒸気レ ーザーを配置しＭＯＰＡ運転を実施しシステム出力 $488 \mathrm{~W}$ 得た。

参考文献; 高橋知幸, 木村博信: J, A t o m, E n e I g g

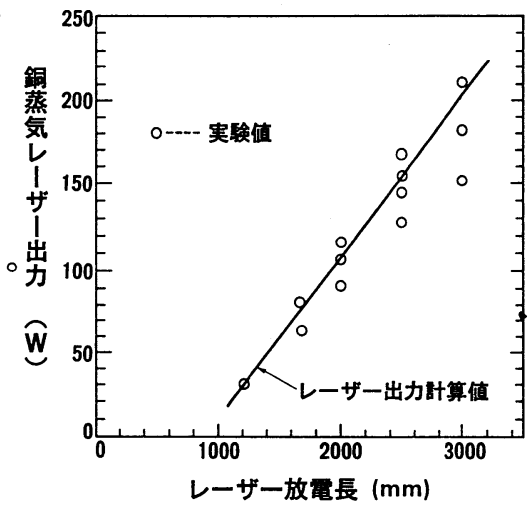
Soc. Japan, $32[5], 476(1990)$.

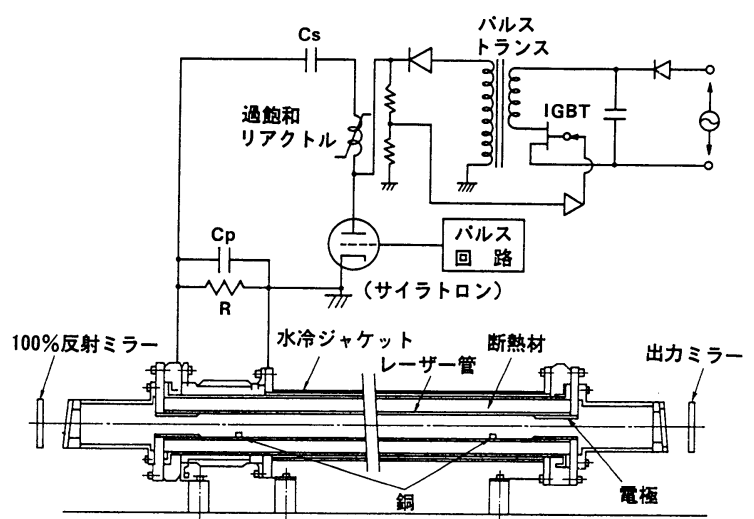

図 1 銅蒸気レーザー栗造図

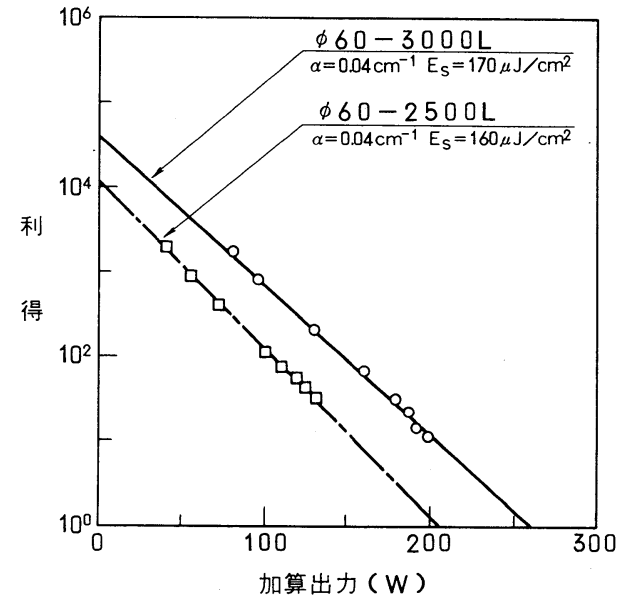

図 3 增幅特性 


\section{平成 3 年レーザー学会学術講演会第11回年次大会}

31 a V 5

Characteristics of Copper Vapor Laser and

Its Application to Dye Laser Pumping

Sungmo NAM, Sangyun LEE, Chulhan $\mathrm{OH}$

(Kyungpook National University)

Operating characteristics of an externally heating type CVL(Copper Vapor Laser) have been investigated for the purpose of dye laser pumping'. optimum conditions were achieved at temperature of $1470^{\circ} \mathrm{C}$, Ne buffer gas pressure of 18 torr, discharge voltage of $12 \mathrm{KV}$ and pulse repetition frequency of $3.5 \mathrm{KHz}$. The laser output power of $2.2 \mathrm{~W}$ with maximum efficiency of $0.58 \%$ consists of $1.5 \mathrm{~W}$ green line $(510.6 \mathrm{~nm})$ and $0.7 \mathrm{~W}$ yellow Iine $(578.2 \mathrm{~nm})$. Pulse width(FWHM) of the laser was $27 \mathrm{nsec}$ and peak power was about $10 \mathrm{KW}$.

A grazing incident-grating type $e^{2,3}$ dye laser oscillator was constructed and wavelength tuning with narrow linewidth was performed. Rhodamine $6 \mathrm{G}$ dye was used as a lasant and the optimum dye concentration was $5 \times 10^{-4}$ (

$\mathrm{M} / 1$ : $\mathrm{MeOH})$. Dye solution was circulated at a speed of $0.81 / \mathrm{min}$ and a specially designed dye cell showed good results. Side pumping scheme was employed and only $510.6 \mathrm{~nm}$ CVL output was used for dye laser pumping. Without a Fabry-Perot etalon the linewidth of laser beam was 3.5 $\mathrm{GHz}(0.035 \mathrm{~A})$ and the conversion efficiency of laser from pumping power to output power was $10 \%$ (unsaturated).
With the insertion of an etalon in the cavity, a single longitudinal mode operation was possible. At a single mode operation the conversion efficiency was low $(0.3 \%)$ and the power amplification by an additional amplifierwas needed. The beam divergence was $1 \mathrm{mrad}$ with beam waist of $2 \mathrm{~mm}$.

Rate equation of the dye molecule was solved to get the population inversion density along the active region of the dye cell. The numerical solution curve was matched well with the experimental curve.

1. I.H. Hwang, B.H. Cha and S.M. Nam, Rev. Sci. Instrum. 58, 1185(1987)

2. L. Shoshan, N.N. Danon and Oppenheim, J.Appl. Phys. 48, 4495(1977)

3. L. Shoshan and Oppenheim, Opt. Commun. 25, 375(1978) 
平成 3 年レーザー学会学術講演会第11回年次大会

31 a V 6

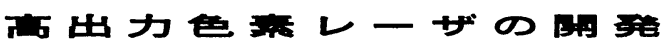

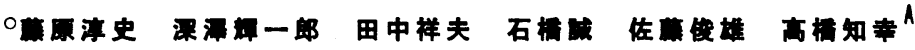

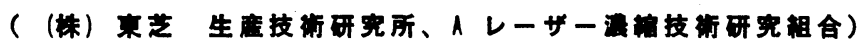

1.はじめに

原子法レーザウラン浱輩に用いる波長可変光源 として C V L 励起高出力色秦レーザを開発した ので報告する。

\section{2. 概要}

開発した色亲レーザは 波長安定化と高出力化 を両立するために 発振器と 4 段の增幅器により 棈成した。

発振器はヘンシュ方式のパルス発振器とし、 波長幅は共振器内エタロンを交換することによ り $1 \sim 5 \mathrm{GHz}$ 亿て 設定できる。また 轵モ 一ド間隔は 共振器長を変えることにより可変で ある。発振波長の揵引・安定化は機密容器の圧力 を变えて行う王力掃引方式を採用した。また発振 波長の計测・制御にはフィソー方式の波長計、 ファプリーペロー干渉計およびマイクロコンピュ 一タなどを用いている。（図 1 参照）

図 2 に発振波長安定性の測定結果を示す。 安定性は $\pm 500 \mathrm{MHz}$ 以下である。

$40 \mathrm{~W}$ 以上の平均出力を得るため、 4 段の增幅 器列を採用した。本色素レーザの性能を評価する ため、ローダミン $6 \mathrm{G}$ 色秦を用い、5 $70 \mathrm{n} \mathrm{m}$ に て $4 \mathrm{kHz}$ の繰り返し数で武験を行った。この 結果最大出力 $51 \mathrm{~W}$ 得た。励起入力 $81 \mathrm{~W}$ 、 色素レーザ入力 $15 \mathrm{~W}$ ○いて 変換効率 $46 \%$ が得られ、全励起入力に対する色素レー ザの効率は $40 \%$ に達している。

色秦レーザの安定性を評価するため長時間連統運転を実施した。出力チャートを図 3 に示す。 平均出力 $41 \mathrm{~W}$ Wて 214 時間の連綍運転を達成できた。

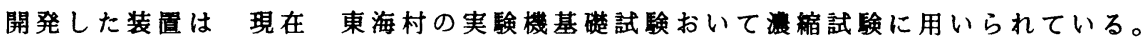

（参考文献）藤原他 - 90 秋応物予稿集 $29 \mathrm{a}-\mathrm{S}-1,2$

深澤他 -90 秋応物予稿集 $29 \mathrm{a}-\mathrm{S}-3$

田中他 -90 秋応物予稿集 $29 \mathrm{a}-\mathrm{S}-4$

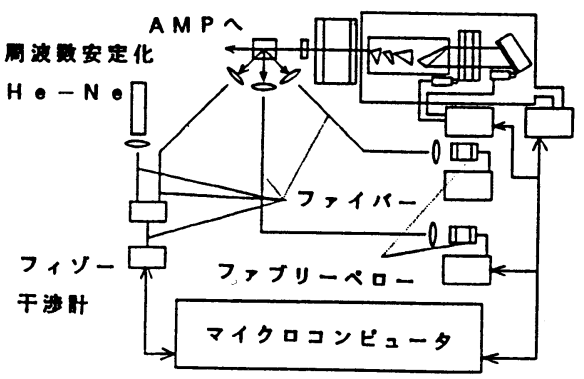

图1発层器システムブロック図

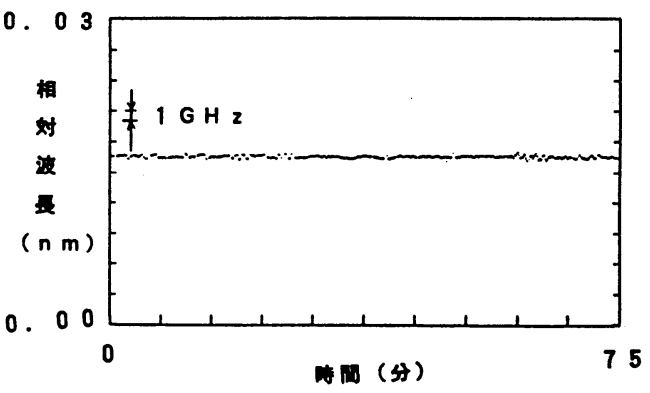

図2吐层波長の安定性

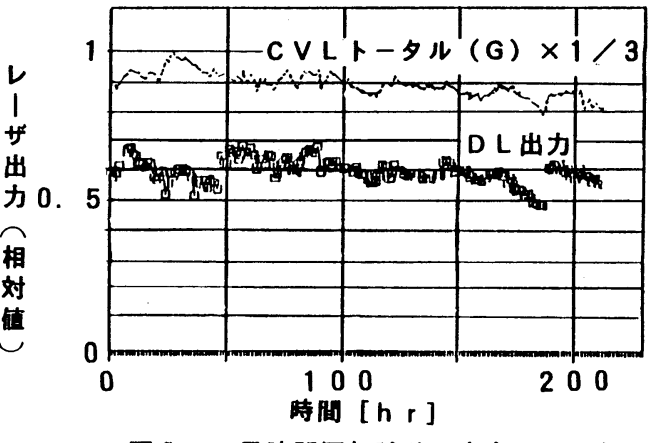

图3長時间速枟式出出カチャート 
平成 3 年レーザー学会学術講演会第11回年次大会

31 a $\quad$ 7

分光分析用色素レーザーの自動化

興 雄司, 出羽達也, 田代英二, 本田親久, 前田三男,

長谷川芳夫†, 二見 博 ${ }^{\ddagger}$ 泉 順

九州大学, †三荾原子力, $\ddagger$ 三荾重工

可変波長な色素レーザーを用いた分光法は特に原子の検知に関して非常に高い感度をもつことか知られ ているが, 我々はこれまで色素レーザーを励起源とし，フレームレスアトマイザーを使用したレーザー原 子蛍光法による純水中の微量不純物原子検出法の実用化実験を行ってきた。 しかし，これらのレーザー分 光法を産業レベルで実用化するには，あらゆる原子の共鳴線に瞬時に同調できるように，広い波長域に速 いアクセスが可能な可変波長レーザーシステムが必要である. そこで我々は従来の色素レーザーが色素交 換などにともなう調整や保守の繁雑さに着眼し，これらを解決する色素レーザーシステムの開発を行なっ てきた.

図 1 に本レーザーシステムの概念図を示す. システムは安定性，信頼性，操作の簡便さ等を重視した設 計になっている．励起用レーザーとしては窒素レーザーを用いた。

色素レーザーは近紫外から近赤外までの波長を連続的にカバーし，さらに SHG を組合せることにより 原子共鳴線が集中する紫外部をカバーしている. 本システムで使用した準封じ切りの TEA 窒素レーザー についてはすでに報告した

色素レーザーはシンプルな斜入射型回折格子を使 用している．色素の交換を目動化するため，色素の 循環系を排し，石英セルに封じ切って内部擋拌を行 なうことで高絽り返し発振に対応している. 色素セ ルはターレット式の色素交換機に最大 14 個セットで き,これらをランダムに短時間でアクセスすること ができる (粼妾する色素では約 0.5 秒)。紫外から近 赤外まで $(360 \mathrm{~nm} \sim 740 \mathrm{~nm})$ を連続的にカバーする 色素を選別し，濃度の最適化を行ったところ 13 種の 色素で全波長域をカバーすることができた. $1.5 \mathrm{~mJ}$ の励起に対し，全域で $10 \mu \mathrm{J}(2.5 \mathrm{~kW})$ 以上の出力を得 ている. 全波長域での同調曲線を図 2 に示す.

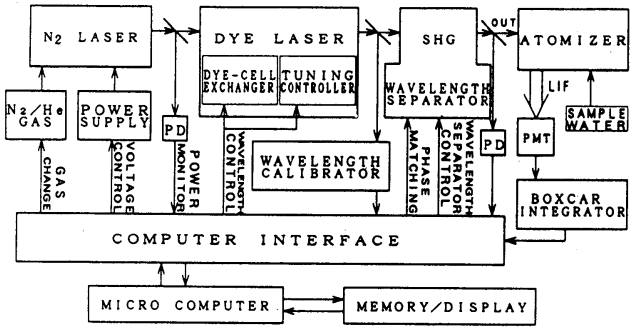

図1. システムブロック図

次に, BBO 結晶を 1 個用いた SHG 装置と波長分離器を試作し，位相整合を目動化したそその結果可変 波長域を $220 \mathrm{~nm}$ 迄拡張することができた. 更にオプトガルバノ効果を用いた波長の絶対校正装置を内蔵 することを検討している.

1) 興 雄司, 宇田尚典, 本田親久, 前田三男, 長倉正昭, 長谷川芳夫, 森本 敬, 泉 順: レーザー研究 18 (1990)79

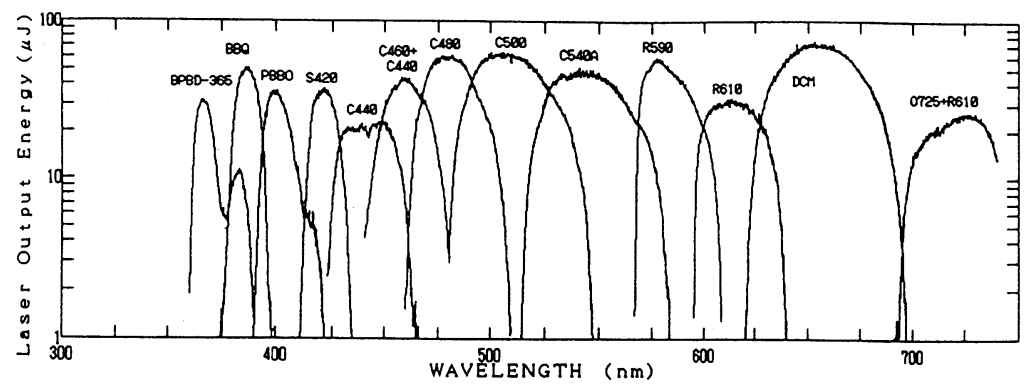

図 2. 色素レーザーの全波長域の同調曲線 
平成 3 年レーザー学会学術講演会第 11 回年次大会

31 a $\mathrm{V} 8$ 高出力真空莱外レーザー用 S i C 共振器反射箁の表面损偒

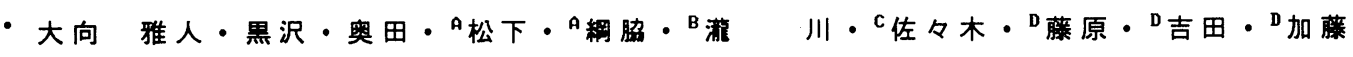

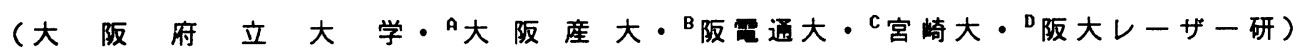

1. はじめに

真空䇣外希ガスエキシマレーザーの高 出力発振を達成するためには損䅞耐力の高 い共振器反射鏡を開発することが最も重要 であるが、現在のところS i C 膜が $47 \%$ ( $1266 \mathrm{~nm}$ ) の反射率と $1 \mathrm{~J} / \mathrm{c} \mathrm{m}^{2}$ (㖕 算值) の損伤耐力を持つ反射鏡であり、 良の鏡である。この反射鏡をM g F 2 透過 鏡と組み合わせてアルゴンェキシマレーザ 一から $80 \mathrm{~m} \mathrm{~J} 、 15 \mathrm{MW}$ の最高出力が得 られている[1]。ところか、このS i C 鏡は作方法によって化学量論比からの組 成のずれや結晶組織の造いによって損伤耐 カに差がある。例えは、シリコン過剩の多 結晶SiC膜の场合には、比较的低フルエ ンスの照射で損甥を受ける。本報告では、

損伤を受けた SiC鏡をラマン敬乱やX線 光霞子分光法を用いて覤察を行い、損賃の 性笽を明らかにし、その発生機楎について 検封する。

\section{2. 実験と結果}

損侮部分を光学顥微鏡で䚁察すると、 アノードパィプの内径に相当する直径 $5 \mathrm{~mm}$ のビームパターンが見られる。ビームパタ 一ン内部には細かい迷図のような盛り上が りが多数みられる部分があり、表面が溶融 状態にあったことが想像される。

図1は末損伤部分（ａ）と損傷部分（ b) の両方から得られたラマン散乱スヘク トルを示す。いくつかの鋭いピークを持つ スヘクトルが見られ、ここで調べた＜wide>iＣ 膜は幾種類かの異なる結晶構造を持つ結晶 組儤在している多結晶であることが分 かる。ところか、（b）には（a）には見 られない幅の広いビークがあり、これはア モルファスのシリコンに見られるピークと 同じものであることから、レーザー損賃は $S i-C$ 結合の切断とそれに伴うシリコン の析出であると結蹁できる。

3.おわりに

S i C反射鏡のレーザー損傷はシリコ ン析出であることが明かとなった。化学量 論比の組成を持つSiCに比へてて、Si1+ $\times$ Cは損穓耐力が低いことが予想される。 在、化学論比の組成のSiCについての 損伤耐カを測定中である。請演では、その 結果についても報告する予定である。
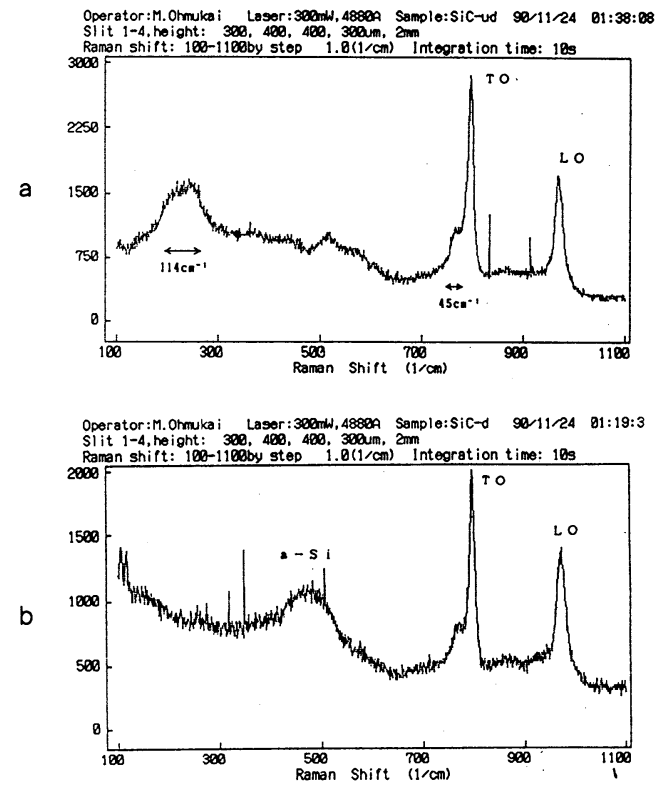

図 1.S i C 反射鏡の未損傷部分（a）と 損傷部分（b）のラマン散乱スヘクトル

[1] K. Kurosawa et a I.: Rev. Scien. Instrum., 61. $728(1990)$. 
31 a V 9

\section{光学薄膜 $の$ 内部応力}

阪大レーザー研，日新電機・

本越伸二, 川口誠二, 前川晴夫*, 吉田英次, 吉田国雄, 中井貞雄

1.はじめに

高出カレーザー用の光学薄膜では、

優れた光学特性、高いレーザー耐力を 有することが必要である。また、他の 分野の薄膜と同样に機械強度や耐久性 なども重要な条件である。レーザー耐 力の高い光学薄膜は、その光学薄膜を 製作するときの点着条件（蒸着材料、 蒸着速度、基板温度、雾囲気ガス圧) を最適化することによって得られる。 しかし、これらの蒸着条件を変化する と、薄膜自身の内部応力も変化する。 一般に使用されている光学部品の光学 薄膜は、高屈折率材料と低屈折率材料 との交互層で構成されている。このた め、単層膜の内部态力が、わずかに変 化しても、多屈膜では大きく変化する こととなり、遂には膜自身にクラック が発生する。

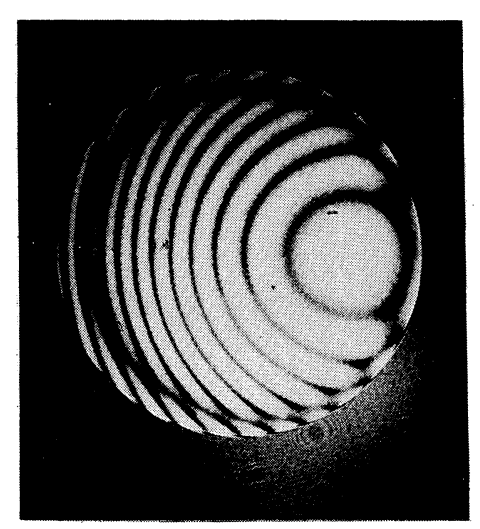

( a ) 蒸着前

\section{2. 実験・結果}

光学薄膜として広く用いられてい る高屈折率材料 $\mathrm{T} i \mathrm{O}_{2}$ 、低屈折率材料 $\mathrm{S} i \mathrm{O}_{2}$ の光学膜厚 $265[\mathrm{~nm}] に つ$ いて、蒸着時の基板温度、酸素分圧を 変化した場合の内部応力、レーザー耐 力を測定した。内部応力の测定には、 厚さ0.5[ 5 m m の合成石英基板を 用い、蒸着前後の基板の反りを干涉計 によって测定し（図 1)、その反りの 変化と基板の物性值より計算で求めた。 レーザー耐力の測定は、波長 1.05

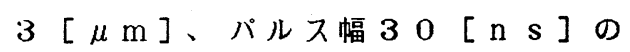
レーザー光を 1 - on $\mathrm{n}-1$ でサプル に照射し、損傷の有無をノマルスキー 顕微鏡で確認した。

また、金属膜等で応力緩和の方法 として用いられている熱アニールにつ いても実験を行った。

詳細は当日講演にて報告する。

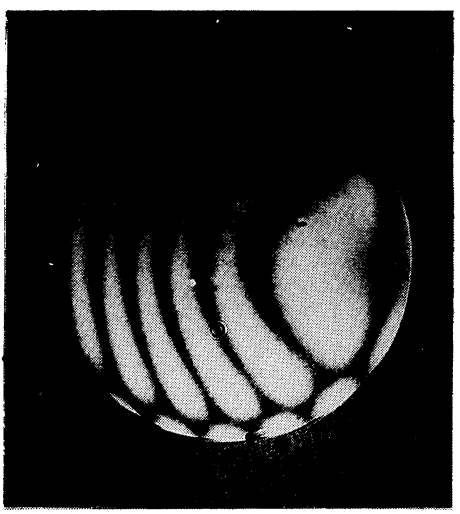

(b ) 蒸着後

园 1. $\mathrm{S} \mathrm{i} \mathrm{O}_{2}$ 膜の内部态力による基板の反り

(基板温度; $300^{\circ} \mathrm{C}$, 酸素分圧; $1 \times 10^{-4}$ Tor r ) 
平成 3 年レーザー学会学術講演会第11回年次大会

$31 \mathrm{a} V 10$ 合成石英ガラスのエキシマレーザー透過特性

東海大学 (工)、山口日本石英 $($ 株) $*$

○松本康孝、小松由和、中原秀起、葛生 伸*、村原正隆

《はじめに》

合成石英ガラスは、紫外域での光透過特性に優れている。このため、紫外光用 の光学材料として広く用いられている。しかしながら、この材料にA r F や K r F エキシマレーザーを照射することにより、欠陥が誘起され、透過率が低下 するものが多い。この現象が起きると、光学材料は光吸収によって熱的ダメーシ を受けたり、屈折率が変化したりすることが懸念される。そこで我々は、その原 因となる透過率低下を抑制する目的で、各種ガス中で材料の䨌囲気熱処理を行なっ た。そしてこれらの材料のレーザーショット毎の透過光量を测定し、熱処理前と 後での值を比較した。その結果、熱処理を行なうことにより透過率低下を抑制で きることが明らかとなったので報告する。

《実験方法》

試料として酸水素火炎加水分解法による有水の合成石英ガラス（タイプIII）で エキシマレーザー照射時に赤色発光のほとんどないもの（A）、弱いもの（B）、 強いもの（C）の三種類を用いた。熱処理は、環状炉を用いて、ヘリウム、酸素、 水素などのガスを流しながら、900 Cで2 時間保持したのち放冷した。そこで、 熱処理前と熱処理後で、図 1 のような測定装置で各試料におけるレーザーショッ ト毎の透過光量を測定した。

\section{《結果》}

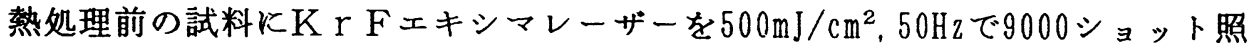
射したが、すべての試料において透過率の低下は見られなかった。

しかし、熱処理前の試料（C）にAＦエエキシマレーザーを9000ショット照射 したところ、1ショット目は85\%であった透過率が、2000ショットまで急激に低 下した。この試料をへリウムガス中で熱処理した後、AｒＦエキシマレーザーを 9000 ショッ照射したが透過率の低下はまったく見られなかった（図2）。した がって、ヘリウムガス中で熱処理を行ならことによって、透過率低下の抑制がな された。

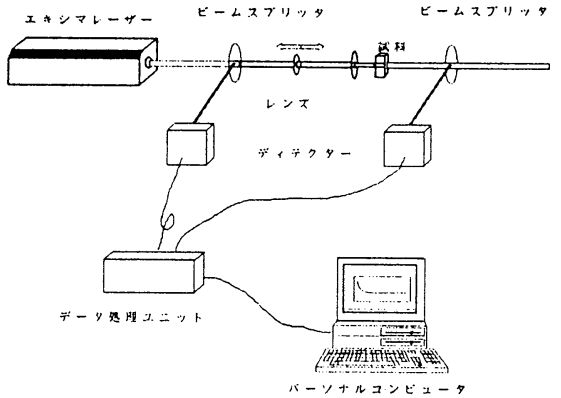

図 1

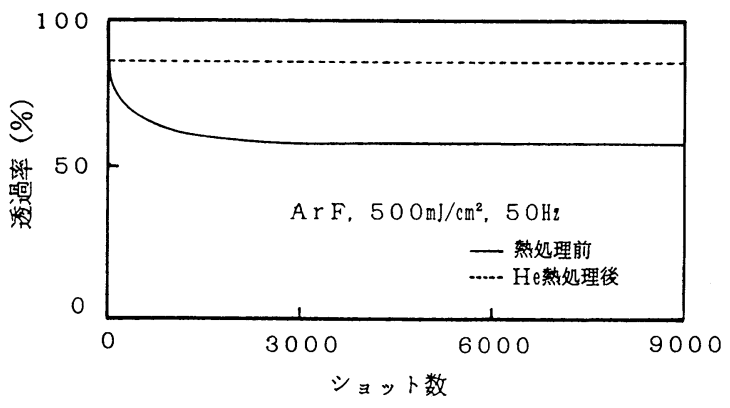

因2 
平成 3 年レーザー学会学術講演会第11回年次大会

31 a V 11

エキシマレーザー照射によるフッ化物結晶の発光特性

東海大（工） ○中原秀起、小松由和、松本康孝、滝沢本承、村原正隆

〈はじめに>

エキシマレーザー用空材は、紫外域での透過率が高く、ハロゲンガスに耐性があるこ とが望まれる。この条件を満たするのとして、 $\mathrm{CaF}_{2}, \mathrm{MgF} \mathrm{F}_{2}$ などのフッ化物結晶があ る。しかし、これらにェキシマレーザーを照射すると、その高いフォトンエネルギーK より欠陥が生成され、可視や紫外域に吸収帯を生じる。欠陥の生成は、材料の純度や製 造条件により様々である。

レーザーの出力低下の原因となるこれらの特性を把握するため、 $\mathrm{Ca} \mathrm{F}_{2}, \mathrm{Mg} \mathrm{F}_{2}$ 結晶 に、エキシマレーザーを照射し、その時の発光スペクトルおよび誘起される吸収につい て調べたので報告する。

\section{<実験方法>}

エキシマレーザー光をレンズを用いてェネルギー密度を変え、アイリスによりビーム

径をそろえ、各試料に照射した。この時、各試料は結晶軸に光軸を合わせている。

A r Fレーザー照射時の発光スペクトルを瞬間スペクトル测光装置を用いて測定した。 また、レーザー照射後の透過スペクトルおよび発光と吸収帯の関係などを分光光度計、 分光ケイ光光度計を用いて測定した。

\section{<実験結果>}

製造条件の異なる 2 種の $\mathrm{CaF}_{2}$ K A r Fエキシマレーザーを照射した 時の発光スペクトルと、9000 ショット照射後の透過スペクトルを 示す。CaFaは2 $75 \mathrm{~nm}$ 抌よ゙ $480 \mathrm{~nm}$ の発光を示すものと、 $275 \mathrm{~nm}$ m発光のみのものとがあり、 9000 *ョット照射後、480 nm に発光のあるすのは、可視から紫外 域にかけて透過率の低下が見られる が（サンプルA）、480 nmk発 光のないものは、透過率の低下は見 られなかった（サンプルB）。また、 $\mathrm{MgF}_{2}$ では2 $85 \mathrm{~nm}$ 执よび5 90 nmk発光が見られ、9000ショ ット照射後透過率の低下は見られな かった。

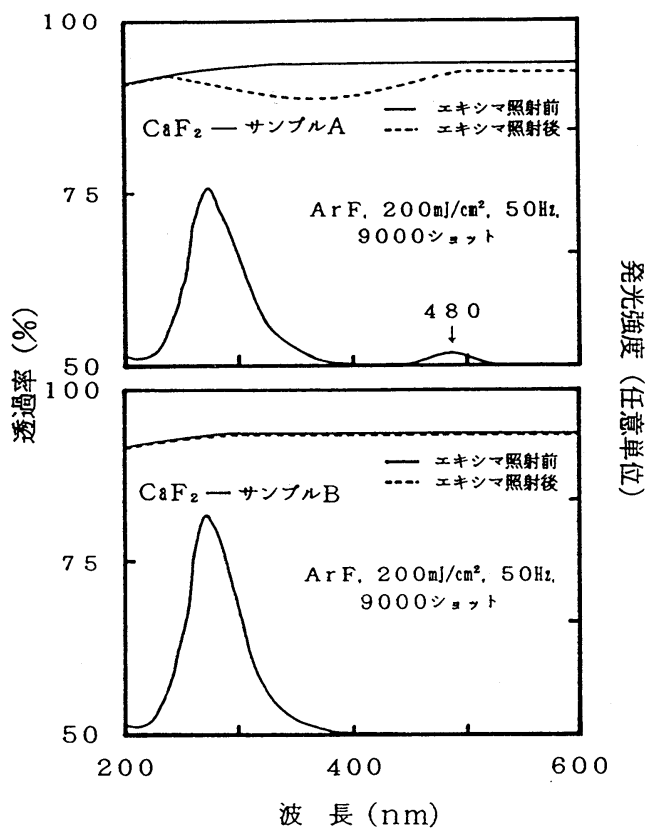




\section{平成 3 年レーザー学会学術講演会第11回年次大会}

31 a V 12

KrEレーザ用フッ化物答反身鏡のレーザアニーリング効果

${ }^{\circ}$ 伊讯孝男、山村史彦、内村龍二、橋本 至、薬王輝雄

大和田野芳郎^、松本裕治^、矢野雅昭 ${ }^{\wedge}$

（炤和光機製造株式会社、^：䉓総研）

[はじめに ]

レーザ核虫合やX線レーザ実駼等に用いられる高出力K r Fレーサシステムには短パルスに対して高耐力な反射鏡が 要求されている。この目的のために我々は、従来の酸化物系多首膜に替わって、より高いレーサ耐力が期待できるフッ 化物系多層膜反射鏡を開発している。これらのフッ化物系反射鏡にはレーザシーリングによつてレーサ耐力が大幅 に向上する現象がみられ、その結果酸化物系の数倍の酎力が実験的に得られている。本講演ではこのレーサアニーリン グ効果について報告する。

\section{[実 験]}

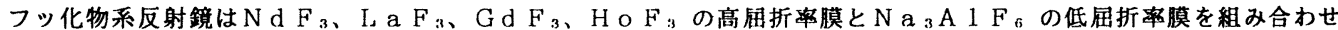
た 4 種類のものについて実弱し、比較として $\mathrm{A}_{1}{ }_{2} \mathrm{O}_{3} 、 \mathrm{H} \mathrm{f} \mathrm{O}_{2}$ の酸化物系も評価した。

ダメージテストはパルス币 $15 \mathrm{~ns}$ の K r Fレーザ(2 $48 \mathrm{~nm}$ )を用い、繰り返し $10 \mathrm{~Hz}$ z p p t s i z e 0. $7 \times 0.4 \mathrm{~mm}$ 条件で行なった。レーザアニーリングもこれと同一条件で行ないショット数、フルーエンスを変 えて効果の依存性を調べた。

[結 果]

（1）フッ化物系反射鏡では、ある照射フルーエンスの䈥囲において繰り返しショットにより拡大しない10〜 $30 \mu \mathrm{m}$ 程度のミクロダメージが点在的に生じた。この現象は酸化物系ではみられなかつた。またタメージが 拡大寸るマクロダメージを基準にすると、フッ化物系反射鏡の中には $\mathrm{A}^{1}{ }_{2} \mathrm{O}_{3}$ 系（耐力 $6 \mathrm{~J} / \mathrm{c} \mathrm{m}^{2}$ ）の 2 倍 以上高いレーザ耐力を示すものがあった。

（2）ミクロダメージ闌値以下のフルーエンス、またはそこから徐々にフルーエンスを上げるようなレーサ照射（ レーサアアーリング)を行なうと、ミクロダメージの発生はなくなり、同時にマクロタメージの閜值も向上し

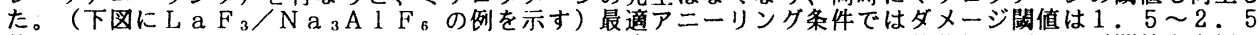
倍に向上し、ベストデータとして $28 \mathrm{~J} / \mathrm{c} \mathrm{m}^{2}$ の閥値を得た。この值は、石英基板のタメージ䦭値を上回る ものであった。なお酸化物系ミラーには、アニーリング効果はみられなかった。

（３）レーザアニーリングの効果は、膜中の最初にダメージを引き起こす何らかの欠陥が修正されることによるも のではないかと考えられる。

1）伊沢他、1990応物（秋）予稿、29a-L-1, P 890

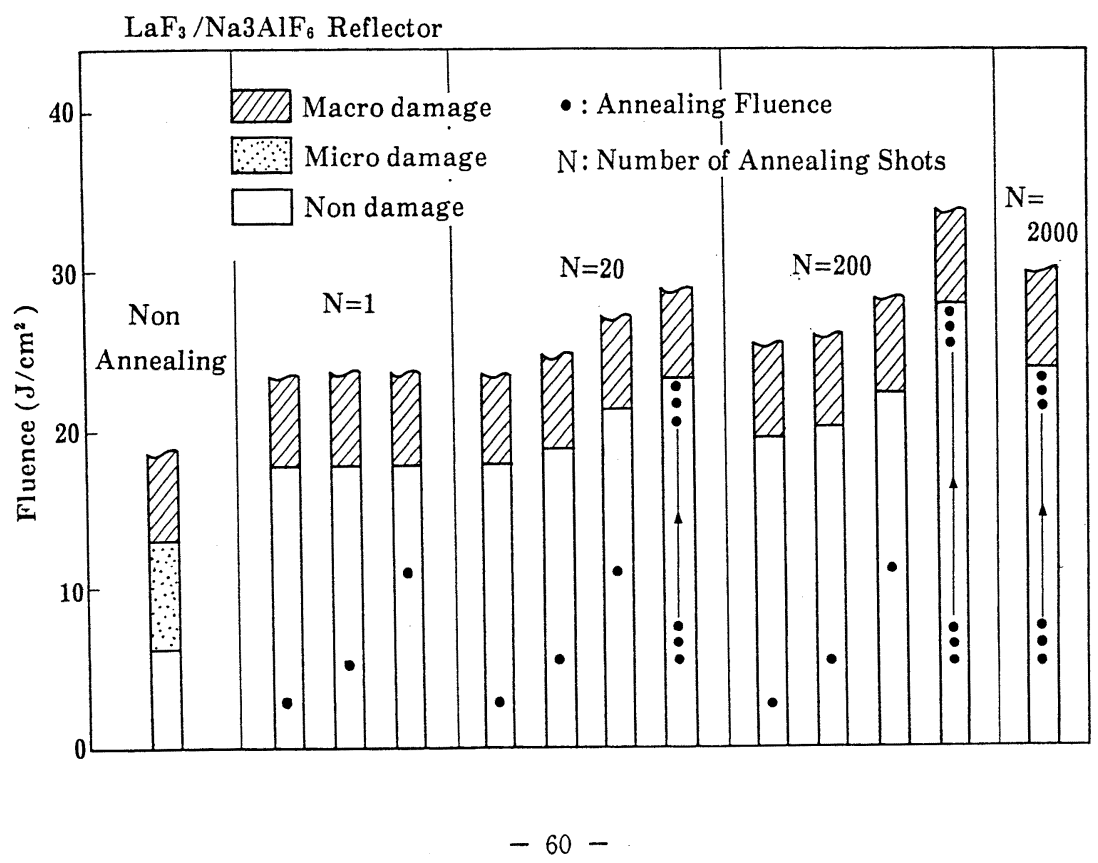

